Portland State University

PDXScholar

Dissertations and Theses

Dissertations and Theses

Winter 3-25-2013

\title{
Phantom Islands A Collection of Short Stories
}

Marie Buckner

Portland State University

Follow this and additional works at: https://pdxscholar.library.pdx.edu/open_access_etds

Part of the Fiction Commons, and the Social Psychology Commons Let us know how access to this document benefits you.

Recommended Citation

Buckner, Marie, "Phantom Islands A Collection of Short Stories" (2013). Dissertations and Theses. Paper 853.

https://doi.org/10.15760/etd.853

This Thesis is brought to you for free and open access. It has been accepted for inclusion in Dissertations and Theses by an authorized administrator of PDXScholar. Please contact us if we can make this document more accessible: pdxscholar@pdx.edu. 
Phantom Islands

A Collection of Short Stories

by

Marie Buckner

A thesis submitted in partial fulfillment of the requirements for the degree of

\author{
Master of Fine Arts \\ in \\ Creative Writing
}

Thesis Committee:

Leni Zumas, Chair

Hildy Miller

Jon Raymond

\title{
Portland State University \\ 2013
}


(C) 2013 Marie Buckner 
Abstract

This collection of short stories takes its name from various islands historically believed to exist and at one time or other located on maps, sometimes remaining on them for centuries, but later removed after they were proved to be illusory. Reports of these islands usually came from sailors as they explored new realms, mistaking actual islands for imaginary ones or by geographical error. Illusions can persist unchallenged for ages. A similar yet modern illusion is the persistence of vision, a phenomenon by which an afterimage, say, on a screen, is thought to persist on the retina for approximately one twenty-fifth of a second. The characters in these stories live their isolated lives as afterimage phantoms on islands that either never existed or no longer exist. 
Table of Contents

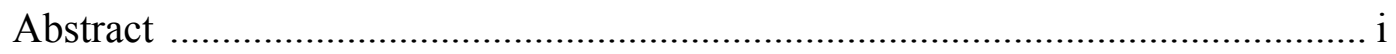

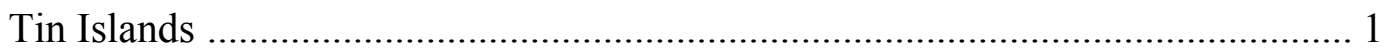

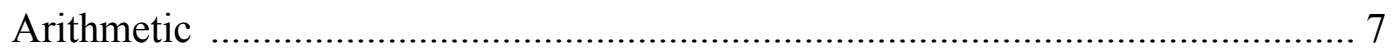

Durable Goods ........................................................................................ 11

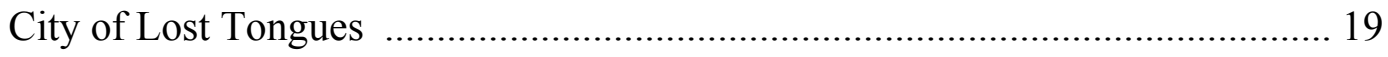

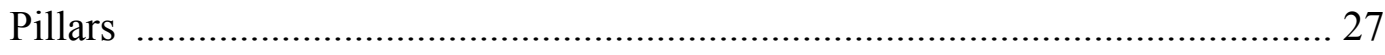

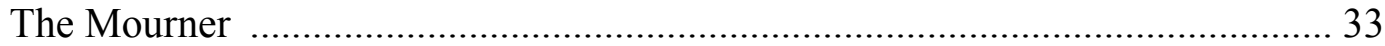

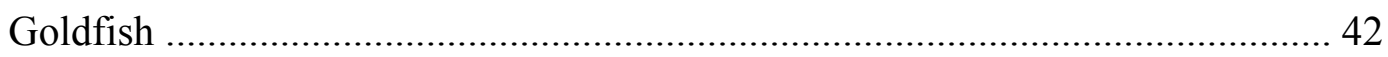

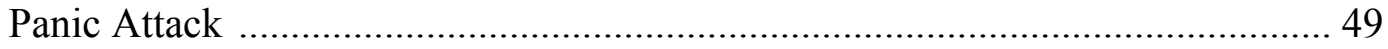

The Street …........................................................................................... 51

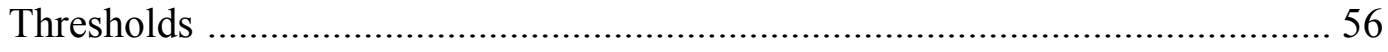

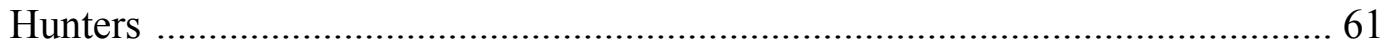

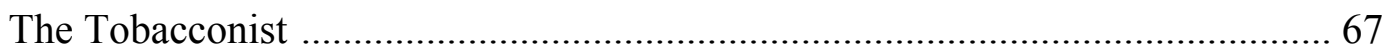

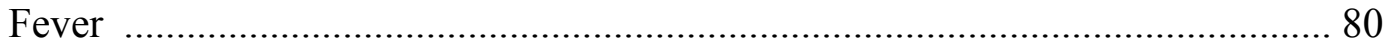

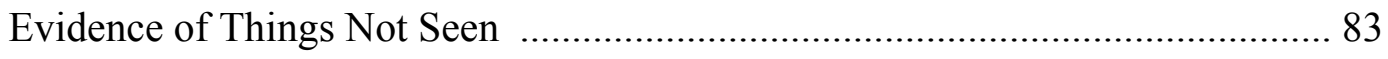

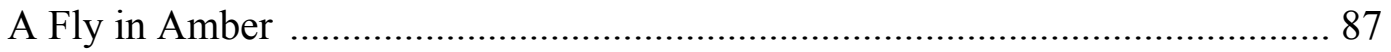

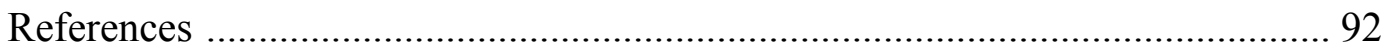


Tin Islands

Back then you could still wander the edge of things. You could still find meaning even as meaninglessness blurred the contradictions between human desire and the tricks of civilization. Back then strangers would stop along highways for strangers, to speed them toward their unknown, flights without seatbelts. If the storm of life had swept away your props and someone picked you up, you gave what you could in return, a small token of appreciation, a joint, say, or a bead necklace, or a song if that's all you had. Such tokens could buy you a long ride. Sudden bonds often held. You could be fairly sure you would not have to settle on a park bench or a sheet of cardboard under some bridge. The strength of the human bond, back then, was often equal to the length of the journey. Driver or rider, often you could end up sleeping on a stranger's sofa or on the passenger side of the bed. In exchange for cooking, cleaning, or foraged flowers, if that is all you had, your road mates would let you stay a few days or a week or two before you moved on. Those were the phantom island days, days believed to exist, even appearing on maps, but later removed after they were proved to be nonexistent. Back then many relationships began on phantom islands, as well as many pregnancies. My pregnancy, for example. My pregnancy was the result of a ride I got one October in a Dodge Phoenix. I was hitchhiking in my yellow cowboy boots with the green stitching on an onramp in Camarillo. I kept a buck knife on my belt for security and cutting cheese. A carload of urban gypsies squeezed closer together to let me slide in on the maroon upholstery and passed me a joint. The driver, an Australian tinsmith, smiled and ran his hand over my boots in admiration. Speed and distance roared through the open windows and lashed our 
hair as we headed south on what was then the busiest freeway in the world, a regular American Dream artery. The ride ended in the City of Angels at a crumbling Victorian where a procession of people stopped by and disappeared and no one seemed to know how the rent got paid. The Australian was borrowing a tree house in the back. It was perched high among the branches of an elm with old windows and lace curtains. In return he was crafting tin shades for household lamps. He had punctured the shades with holes to depict scenes I recognized from J.R.R. Tolkien. Back then, everyone who could read was reading Tolkien. That first night I sat on the kitchen floor peeling garlic. I kept getting distracted by the mighty bulge in his crotch as he leaned against the sink with a bottle of Stroh's telling stories as the cooking crew made spaghetti, garlic bread, and salad. Back then conversations turned interdimensional and conventions were barriers to understanding. Full of dinner and wine I climbed the ladder of the tree house with him behind me and we went at it under a quilt of moonlit squares made by a many-paned window. He was twenty-three and lanky with pale hair and the beard of a mountain rustic. His false teeth were the payoff from a motorcycle crash. He was tin-smithing his way up the West Coast to get back to Australia and marry his girlfriend.

I gave birth to my son at two something on a July morning on the floor of a gas station restroom somewhere in Arizona with all the usual pain and dread. He slid out between my legs on a shabby rabbit skin coat. I caught my breath and cut the cord with my buck knife. He cried a little and seemed healthy enough, so I swaddled him in the coat and cleaned up the bloody mess with brown paper towels and handsoap. That night I dumpster-dove for uneaten food behind a truck stop where I found heads of lettuce, heaps 
of sandwich buns, decks of sliced cheese. I gathered a hoard of individually wrapped saltine crackers and made it my dinner. Back then the dumpsters had no locks and they didn't arrest you for stealing thrown-away food.

I could not afford to buy diapers, so I learned my son's signals and rhythms and held him over the dirt behind some bush or building. I spent the night with him in my arms against a shed in a used car lot. It was too hot to sleep. The next morning I tied him to my breast in a shawl and along the way a sweating mechanic rolled out from under a car to tell me about a place across town where I could find piecemeal work making swamp cooler pads. I thumbed a couple rides to a big tin shed and climbed the side steps up to the office. The guy who hired me was from Bakersfield. He looked like Orson Welles minus two fingers on his right hand. He gave me half of his sandwich and a tin cup. He told me I should drink plenty of water. Inside the shed a couple dozen Latinos and whites worked furiously, each over a flat wooden box on legs. A wide roll of gauze was attached horizontally to one side of each box. The supervisor, a boxy woman with tobacco-stained fingers, said the trick was to roll double the gauze to fit inside the box and let half of it hang outside. You had to keep adding wads of curly wooden spaghetti, which she called excelsior, to a bucket of water to let soak before spreading not too thin and not too thick over the gauze in the box. The last thing was to fold the other half of the gauze over the excelsior and staple the edges to make a firm pad. She said that once installed in the frame, air would pass through six water-soaked pads and pick up humidity as the wood absorbed some of the water. The wood fibers would cool passing air to a lower temperature. People who could not afford air conditioners bought these evaporative coolers to mount on their roofs or in their windows. 
By mid-afternoon the tin shed could have baked a pizza. My son's hair stuck to his head as he slept and nursed and whimpered a little. I made many trips to the water spigot to drink from my tin cup and douse him with water. We all stacked cooler pads like hotcakes on long wooden shelves.

The pay was fifty cents a pad. The first few days I was so clumsy I could only make a few cooler pads. But as I got faster I made more money, enough, in fact, to buy a box of diapers and a six-pack of root beer and a little food from the convenience store, enough, even, to rent a six-dollar motel room. It was on the ground floor alongside a stretch of highway that rippled glassy waves. At night insects churred and chafed in the greasewood out back. The room smelled of disinfectant. Its walls were flamingo pink and mint green. The small refrigerator was broken and the air conditioner thundered warm air, so I kept my sodas cool in the toilet's holding tank. After work there was nothing to do but watch television while my son slept between pillows on the motel bed. He did not ask for much: my breast, diaper changes, sleep.

Badgers sat around a table playing poker on black velvet in a frame over the television, and on top of the television the name of the motel was printed on the bottom of a tin ashtray. I drank root beer and tried to make sense of the horse shit coming out of the television, mostly Watergate jabber and the Viet Nam War, all the usual confusions and received anxieties. Five channels came in clear enough to watch. When I got tired of the news I turned to cartoons and miracles performed on a faith healing channel based in Selma. In one miracle a fat man who could only wheeze and make guttural sounds ballooned on the stage of an enormous meeting hall in front of a faith healer, a scrappy man with a few strands of hair on his head and skin the color of a boiled tangerine. I kept 
getting distracted by the fat man's enormous chin. He had so much neck fat that the back of his tongue got stuck in it and he nearly choked when he tried to speak. The faith healer, in preparing the audience for a miracle, closed his eyes and lay one hand on the fat man's shoulder and the other on his forehead. The faith healer disgorged a prayer and commanded everyone to witness a whole evening of miracles, a shameless series of bankable marvels and grand flimflam. After more praying he grabbed the goiter and shook it with a violence you rarely see in church. The fat man teetered on his heels. The faith healer rolled back his eyes and raised his arms in flight formation. With sudden force he shoved the man who careened backward onto the stage into a thumping, lumpish pile. The fat man grunted himself to a sitting position and brought his hand, the size of a small frying pan, to his neck. Slow astonishment spread on his face like syrup. He opened his mouth, as if to receive something in it, and hesitated. His eyes widened to the size of stew pots. He garbled and he gurgled, and when he finally produced a clear word of astonishment, a gasp erupted over the congregation like a wave. The fat man's forehead glistened as he got on his hands and knees and stuck his head between the faith healer's legs, grasping them in his arms where he pulled himself up like a chubby shoaling goldfish. Everything in the meeting hall strained with hush until he blubbered a little and fell against the faith healer who yelled Praise the Lord! and sent him careening again, submerging him into a phantom river of baptism, and just before the fat man fell caught his arm and held it high, tearing him from a phantom birth canal with an inversion and a conversion to shock the breath back into his lungs. As a unit the congregation was dazzled to its feet, applauding deliriously, swaying and shouting, Praise the Lord! Amidst 
the razzle-dazzle a coiffured woman in a curvaceous pink shift, pink heels, and permanent smile ushered the dazed fat man offstage.

The faith healer pranced around the stage with his microphone shouting and gesticulating as he swept down the steps into the adoring audience. He chose a young black woman and pulled her back to the stage with him. She had milky blue eyes that protruded as if with some internal pressure. He had a lot to say to about the woman. As he hailed a barrage of prayers she sneezed into the crotch of her arm and licked it clean. The faith healer howled. He pressed his unoccupied hand over her eyes and pumped out rounds of Hallelujahs, whipped the audience into a moment of threatened consciousness like the parting Red Sea as hundreds of pairs of eyes strained to see the spectacle of a blind woman seeing. I thought it was a shame that if he healed her she would only see what the rest of us saw. My son stirred in his bay of sheets and blankets on the motel bed. In a moment he would be fussing and straining. I told him that none of us were what we saw. I sat on the bed and took him in my arms. Excitement and dismay caught in me like papers in a windstorm against a wire fence. I had brought to earth another scarred meteorite of human desire. I sang "Miles from Nowhere" to him while he nursed and the badgers played poker over the television, forever staring at the hands they'd been dealt. 
Arithmetic

I had my daughter's boyfriend's baby. It was early in her senior year in a new high school, the same year my husband's company transferred the three of us to Weatherby. We did not know she sneaked out of her bedroom window every night to see a boy we had never met.

Actually, I had met this boy. I just didn't know he was her boyfriend. It was the same day she had asked me to check out a book for her honors English class from the downtown library. I managed to find the British literature section. This boy was bent sideways at the far end of the aisle, his hand sliding over volumes as he moved along toward me. I noticed him because of his dramatic, monochromatic persona: wild black hair, black clothes, black Converse sneakers, gray eye shadow. When he reached the shelves where I was pretending not to notice him he straightened and smiled at me. He was tall enough to read the titles on the top shelf at eye level and he smelled mysterious and free, like a cool, dark forest. I was thinner back then and looked younger than my age. He pointed to the copy of The Romantic Agony in the crook of my arm and asked if I fancied Romantic literature. I told him I had read many romance novels and enjoyed most of them. He told me he preferred decadent literature from the late nineteenth century and mentioned the names of several unfamiliar writers. The only name I recognized was Edgar Allen Poe. What stood out from what he said, though, was the word “decadent." It sounded a little naughty, like being seen in public with a boy my daughter's age. My husband and I used to be a little daring before our daughter was born. But I couldn't recall the last time I had done anything naughty. 
The boy and I strolled to the downtown park carrying our books. It was a warm afternoon filled with long gold light that deepened everything it touched, a fleeting glimpse into somewhere, something else. Squirrels jumped through branches over our heads and our feet crunched acorns and twigs along the paving stones. The air smelled like dry wheat and people hurried around preparing for winter. Everything had an urgent feel to it.

He told me he had graduated from high school in June and was now a cosmetology student at a local beauty school. He semi-lived with his Hungarian mother and her two husbands, one of them an ex-husband. She had been married six times and worked as a black jack dealer in a tribal casino. He said she had changed her story so many times that he did not know which of her husbands was his father. We bought coffee in paper cups and caught a streetcar to Weatherby Park. He said the park had once been a cemetery. He slept there sometimes on warm nights because the dead were so quiet. The park was surrounded on three sides by an old stone wall and a hill that sloped at its western edge. We entered through stone columns that, he said, once supported a beautiful iron archway. Evergreens and oaks dotted a grassy landscape where people wandered while their dogs ran around and relieved themselves. A sudden wind rushed through the trees; slate clouds soared in the western skies. He told me that in the 1960s the city had removed thousands of headstones that families had paid for dated from the early nineteenth century. Nowadays thousands of pioneer families and war heroes lay forgotten and untraceable under the grass.

We climbed to the top of the hill where oaks and evergreens battled in wind currents over two white marble tombs that looked out over the harbor and its sailboats. 
The tombs were marked with graffiti and the names John Weatherby 1822-1886 and Harriet Weatherby 1831-1893 were carved into them. We sat down on John Weatherby's tomb and gazed out at the view. He pointed to a jetty and said some believed the city had built it with the broken headstones removed from the cemetery. He told me he spent much of his time at that secluded spot watching the sea and waiting. What I remember most about that late afternoon were the softness of his lips and the smell of forest on his skin.

It had rained the evening our daughter led him into the kitchen to meet the parents, who were eating slices of cold pizza and arguing over something I don't remember. The boy had carved his stone face with a smile. I did not smile or look him in the eye when I shook his hand.

When I learned I was pregnant I burned all my journal pages where, like a school girl, I had written wild, romantic fantasies about the boy. The due-date arithmetic did not add up to favor my husband, but since no one thought me capable of being anything but a faithful wife, we all agreed that the doctor had miscalculated. Which was lucky for me since women caught having sex with underage boys usually deliver their babies in prison. I never saw the boy again. I learned he had gone to London to live with a boy he had met at cosmology school.

The summer my son was born my daughter had graduated from high school and would be going to a small liberal arts college. We were in her bedroom. She was sitting on her bed and I was at the window, looking out through a trellis of pink roses. I told her she was an adult now but I knew she used to sneak out at night to see the boy. It was an odd conversation, a mother calmly mentioning a daughter's transgression without anger 
or disappointment in her voice, but a hint of something else. Perhaps it was melancholy. My daughter came up from behind and put her arms around me. We stood there swaying, cheek-to-cheek in silence for a long time.

That fall she brought home a boy she had met at college. He was shy in his Oxford shirt and leather jacket. We all sat around the kitchen table over coffee and pound cake. The sheer kitchen curtains bellied and sailed on currents from the sea, dry wheat fields, and urgency.

As I cleaned out closets and drawers for our next move, I found a photograph my husband had taken of our daughter and I sitting under an arbor eating ice cream cones. She would have been in first grade. On that day we'd watched a spider spin its web beneath a grape leaf. She asked me why spiders didn't stick to their own webs. I told her I didn't know but it was probably some mathematical principle. Just as I said that, a moth flew into the web and caught there. Its wings fluttered in a desperate blur. We licked our ice cream cones and watched the death, the drama, the dance. 


\section{Durable Goods}

Around the time my friend Inez started selling Tupperware I told her about my fear of intimacy, about all the bad relationships I'd had, about the mess I'd made of my life. Newspapers spread over the floor stuck to our feet as we painted her kitchen. Turquoise paint smeared our hands and faces. I told her I would change things if I could. If I could go back to meet myself when I was twelve I would tell my younger self that one day she would have three grown daughters. I would tell her she would not abandon her children as she feared she might do. She would not let them down the way I was let down. I would assure her that the adoption agency worker would not kill her and cut her unborn child from her belly. I would tell her this to save her from the nightmares that had waked me each night from fear of losing my children. I would tell my twelve-year-old self that she was not a mistake, to prevent her living a lifetime feeling that she was. She must not apologize for everything that happened. Everything was not her fault. She must not apologize for her existence. She was meant to be here and she had as much right to be here as anyone else. That even though she had been sacrificed to the adoption industry for a handsome profit, she deserved healthy relationships in life. I would say that she would need to choose men who treated her with respect. She did not have a curse on her that made her unworthy of caring and love. That loving herself would be the greatest gift she could give to herself and her future children. That way, when she looked into the mirror she would know she was going to be okay. I liked Inez. She was a good listener like her Aunt Pepita. 
When I moved into my house after the divorce I had cried all afternoon after discovering that none of the plastic lids in the kitchen drawer fit any container. Mismatched containers and lids are one of those household mysteries, like missing socks. Fortunately Tupperware parties were big then, like hair, and later I met Inez who lived down the street from me. She invited me to one she was hosting. A crowd of women milled around Inez's living room. I did not know any of these women except Inez. I stuck a nametag on my lapel and circled the tables where Tupperware sat on display along with a pile of pamphlets, binders, and party tokens attendees could take home. Cardboard boxes with more Tupperware sat beneath the tables. The folding chairs got filled. Eager faces watched Inez demonstrate new Tupperware products like the hospital-green cheese grater and the ketchup-red lunch box with little containers that fit inside. She told jokes and put everyone at ease.

After the demonstration she found me munching an Oreo and eyeing a Tupperware display stacked up like a small city. She asked me what I thought about the opportunity and reminded me that it was my chance to be my own boss, have fun, and make money. I brushed cookie crumbs off my jacket and told her I had just come to buy the 54-piece set of sturdy new containers, each with its own lid.

She told me that was not how it worked.

I said what did she mean that's not how it worked?

She rolled her eyes and said that this was a party, chica, not a store (she called me chica, which means "girl," a term of endearment that included me in the circle of her friends and family and gave me a sense of belonging). She explained that at these parties 
the hostess displays and demonstrates Tupperware products. Afterwards she took orders. She got a commission on whatever she sold and a commission based on her recruits' sales and discounts on Tupperware.

I grabbed another Oreo and held up a hospital-green gelatin mold. "You mean I have to be your recruit to buy this?"

Her eyes flashed as she took me aside and rasped into my ear: Mira, chica, haz lo que quieras, which meant, Look, sweetie, do it if you want. She meant I could become one of her money whores if I wanted. Maybe it would be worth it. Maybe it would give me structure and delineation, a sense of rootedness. Roots had never gone deep for me. I longed for things that lasted, but they never seemed to work out. I held up a set of four nested bowls with matching lids and asked her how much they were.

She put her mouth to my ear again and whispered that they were too much. I must have looked lost. In a normal voice she said she had invited her Aunt Pepita and her friend Lupe to dinner and that I had to come too. She would hear no excuses.

After everyone left the party with their purchases, we walked up the street to Beto's Market. It was painted red and white like a barn. A small boy had his pants down and was urinating on the leg of a gumball machine outside the door. Inside it always smelled like turned meat. We bought flank steak from the butcher counter and cheddar cheese because, like the white person I was, I liked it on my tacos. Most of the vegetables in the produce section had stickers on them that said, GROWN IN MEXICO. On top of the mirrored produce cases piñatas were crowded among gaudy plaster figurines of piggy banks and Virgines de Guadalupe. I helped Inez pick out tomatoes, limes, onions, jalapeno peppers, and cilantro. 
When we got back to Inez's house, Pepita and Lupe had let themselves in. They were already drinking from one of the three bottles of ready-made sangria they brought. Aunt Pepita was a large woman and she came with Inez as a packaged deal, as part of her large family. Pepita had a way of dislodging the peace and getting people worked up. On her street one of her nicknames was the M-80 Lady because after a few drinks she got so loud that electronic garage doors opened, car alarms went off, and her neighbor's Schnauzer howled. People who did not know her would grab their children and pull them indoors. In her life she had had plenty of experience with beginnings and endings, things that had to do with weddings, funerals, and divorces in her large family. Everyone who knew her accepted her as a tiresome woman who knew better than anyone how to bring grief to the comfortable and comfort the bereaved.

After my divorce, when I had first met Inez, Pepita invited me for coffee. We sat at her dining room table. She talked a little about a bordello she had visited once where everything was dark and sticky. But the reason she had asked me over, she said, was to read my fortune. She winked and told me she used to be known as the Tipsy Gypsy. She took out four cowries shells and threw them onto a special mat. The shells that landed with their slit side up she said were "open" because they were like mouths with teeth that could speak. I thought they looked like tiny white vulvas with teeth. Those with the other side up had been filed to expose their inner shell. She said those were "closed." She told me I could only ask a "yes" or "no" question for five possible answers. Three open shells and one closed one landed on the mat. She said I would have many delays or obstacles but I would get what I wanted after much hard work. I cannot say why, but her shells calmed me down. 
The four of us who hung around Inez's turquoise kitchen drinking sangria that afternoon knew about loss, some more than others. We were all were divorced except Pepita, who was a widow. Lupe and Pepita had grown children and Inez's ex had custody of her two sons. But I was the only one who mourned her lost self. I had no words to talk about it. Pepita poured herself a refill and heated up a flat skillet. She and Lupe shaped tortillas out of corn masa while Inez grilled strips of spiced flank steak with lime. I sat at the table grating cheese on the Tupperware grater and cutting up the vegetables to make salsa, extra hot the way they liked it.

Pepita flattened a tortilla and tossed it onto the skillet. She told Lupe to go back to her doctor. "You need a pill, chica. You're depressed. Look at your eyebrows."

Lupe had plucked them all out and penciled in black lines that looked like bird wings. "I tried to adjust myself," she said, "but I can't take those pills. Doctor Janet made me stay and get a pap smear and I said, Oh my god this is why I don't come and do this."

Pepita was just warming up. "But you need to go. They can pinpoint it."

Lupe vigorously rolled a ball of masa between her palms. "My mother is 87 and they wanted to give her one too. All these women are dying of cervical cancer."

“Aw Lupe, don't be such a chicken."

"I got to psych myself up is all. I got to get my period."

With food heaped in Tupperware containers, everyone sat down around Inez's table. We offered a toast to friendship. Glasses up, a clink, a drink. We piled strips of flank steak on the tortillas and folded them in with lime and salsa on Tupperware dinner trays. My mouth burned with hellfire and tears rolled down my cheeks. I chugged my 
glass of sangria. Lupe dabbed a napkin at her mouth and asked Pepita if she had heard from her sister-in-law lately. Pepita licked a morsel of meat from her lip. "She drinks it all."

Everyone stopped chewing and looked at her.

Lupe said, "She drinks all what?"

"Jim Beam. Pints of Jim Beam."

"So that's why she was talking to you on the phone," Lupe said. "She was drunk." Pepita helped herself to another tortilla. "And four packs of Pall Mall Longs a day." "She's on meds and she drinks it straight?"

"Straight no chaser. First it was a coffee cup. Now it's straight down and smokes back-to-back."

Lupe's face was a puddle of disbelief.

"Plus there's something dead in her house," Pepita said. "I told her I'd do anything she wants but I'm not looking for no dead rat." The loudness of her voice began to raise alarm around the table.

“She's got rats?" Lupe dropped her taco. Salsa dripped from her fingers like blood. She stood up and carried her plate to the trash.

"Not mice. Rats. Big ones." Pepita held her crimson-nailed hands about a foot apart to illustrate their size. "But there's a lot of other stuff living in there too. Her son was sitting on the sofa watching TV and a roach crawled on his neck. I saw it." "Aunt Pepita can we please change the subject." I poured everyone another glass of sangria and we all floated toward living room furniture. Inez opened the front door to let in some air along with a sparrow. Pepita 
shrieked and waved her arms at the sparrow shouting, "Bird in the house means death!" All of us ran around chasing the sparrow, trying to make it fly back outside. Pepita had enlarged her voice to M-80 strength. The sparrow dropped dead on the floor. Lupe said Pepita had given it a heart attack, but Inez said it was just a coincidence. The bird was probably just old and looking for a place to die.

Inez invited me to another Tupperware party where I agreed to be her recruit. She gave me a thick binder full of instructions and forms. "Now remember," she said, "always demonstrate how to burp the containers, press the air out so the food stays fresh. And make sure you don't close your parties without adding at least one new recruit." She elbowed me. "That's how you gain confidence in yourself and make money doing it."

That week-end I drove around to yard sales and garage sales where I spied, curved above an infestation of gewgaws on a long table, a strange blue glass bottle. It had a graceful, swan-like neck with a flat narrow opening shaped like a flower petal. I asked the white-haired woman what kind of bottle it was. She left her lawn chair to talk with me. She wore fuchsia lipstick, enormous plastic bangles, and earrings with miniature scenes of snow geese carcasses floating on a toxic lake in Montana. She told me the bottle was a tear catcher from Persia. She demonstrated by holding the petal opening over her eye. She said it was very old and that Persian women kept such bottles handy in their homes ready for times of grief. I bought it from her for Pepita wondering how it had survived so much grief and traveled so many miles without breaking and how many generations of women had used it. 
That evening I put all my mismatched containers and lids into a brown paper shopping bag, ready for whatever they did with recycled plastics. It was good to clear out the drawer and wipe it out with a damp cloth. I stared down into a clean, empty space that would be filled with a fresh set of containers, objects that would outlast us all. 
1.

By the second week of school Sydney and Maxine became best friends, the only two sixth graders at Padwick who belonged to The Society of Lost Tongues. That is, they would have belonged to it if it had existed, if they had thought to invent it. Syd and Max were two of the only day students at Padwick Boarding School. Kate Wyatt and her friend Iris Bodley were also day students. Kate Wyatt's mother was Padwick's sixth grade teacher. That year Mrs. Wyatt had fifteen children in her class. They spent the first three months reading Northanger Abbey and studying Greek mythology. Perseus was a big hit. The day the class read

Lest for my daring Persephone the dread, From Hades should send up an awful monster's grisly head at recess Kate said Syd's curly hair looked like snakes. They began to call her Medusa with delicious cruelty. And since Max was a few pounds overweight, she became Maximum the Gladiator, Maxi Taxi, and finally Maxi Pad. During recess other classmates joined Kate and Iris and ganged up against Syd and Max between the shop building and the high juniper hedges. Mrs. Wyatt was a long-faced woman with cocker spaniel eyes. She always dealt with such things by sending offenders to the headmaster's office. But since she was nearsighted by nature, Kate and Iris easily convinced her that Syd and Max were calling them names and bullying them.

In the locker room just before Christmas vacation Iris caught a glimpse of Max's first shy strands pubic hair and informed Kate. The two of them whispered behind their hands and giggled with long glances at Max. Soon other kids at school were nudging 
each other and snickering at her. During geology, as Mrs. Wyatt set out trays of feldspar, quartz, and calcite, bouts of whispers and laughter rippled through the room, all heads turned toward Max. Mrs. Wyatt planted her hands on her hips and sent a hideous, myopic gaze around the room, turning some of the more timid students to stone. Fingers pointed to Max, whose face throbbed with mortification. Mrs. Wyatt asked Max a question, but Max could only stare down at a dark spot on her new sneakers. Mrs. Wyatt said very well, then, maybe Headmaster Boskell would help her find her tongue and sent Max to his office.

At Syd's house Max and Syd climbed trees and built forts. Max was Tom to Syd's Huck. Max would go home saturated in childhood, with torn clothes and leaves and tangles in her hair. Syd's father, Mr. Owens, was an off-shore oil rig roughneck. Whenever he was home, he bought them beef jerky and said the were regular tomboys. Mrs. Owens, who had always wanted to be a pianist, worked two jobs to pay for Syd's piano lessons. All the piano teachers ended by telling Mrs. Owens that the lessons were a waste of their time and her money.

At Max's parents' house they watched television. The Radford's long, low ranch house with its swimming pool had been custom-built beneath sheltering oaks in the wealthy part of town. Its rooms hung with a green, orchidaceous scent, although there were no visible flowers anywhere. Syd marveled at the paintings and art objects tastefully displayed in every room, each feather-dusted by an Albanian maid who did not speak English and whose habit it was to click her tongue when she was out of sorts. Max's 
father, Dr. Radford, was a brain surgeon, often away on lecture tours and doing whatever else brain surgeons did. Mrs. Radford sipped perpetually on highballs, ice clinking in a hand-blown glass. She was known to greet guests with nothing on but a pair of high-heeled slippers and a towel. Her slipper collection was a menagerie of preserved feathers and skins—zebras, leopards, flamingos, ostriches—-perched and stabled, ark-like, on custom racks in her capacious closet. When she walked her slippers made a soft sound against her heels: Flack, flack, flack. When the Radfords remodeled their kitchen, Mrs. Radford would emerge from her bedroom wrapped in her towel, letting it slip at the most advantageous moments, for the benefit of the carpenters, electricians, and tile setters. Sometimes, when Syd spent the night and the Radfords went to a cocktail or dinner party, the maid would babysit. Syd and Max ate their meals alone on the clear glass kitchen table. Syd could see her sneakers below the peas and chicken leg on her clear glass plate. For as long as Syd had known Max, she had never seen Max's sister whose bedroom door remained locked at the end of the hallway. Whenever Syd asked Max where her sister was Max would only shrug. Sometimes Mrs. Radford's story was that the sister was away at college. Other times the story was that she had gone to live with relatives. Once Syd went to get a drink of water in Max's bathroom. A green nightlight fanned light over the wall. She drew tap water into a glass and took a mouthful. A small soft thing rolled over her tongue. She spewed the water. A wilted spider dragged itself around the marble sink.

Syd got Cs and a few Ds on her school work. Mrs. Owens signed her report cards, 
but not without a lecture about what other people would think. But she never said who these "other people" were. Mrs. Wyatt said Syd did not apply herself. Max was an A student, a fact that Dr. Radford never acknowledged. For getting a single B on a quarterly report card he paraded her by the ear around the huge rooms of their house. Mrs. Radford flicked a silver lighter at her cigarette and stared vaguely at the spectacle through a bouquet of blue smoke, as one might watch a forklift scoop up a sick cow.

Mrs. Radford smoked too much. Twice she fell asleep with a cigarette between her fingers and set her towel on fire. Another time their neighbor Mr. Upstone was out watering his back yard when he rushed to fish her from floating face down in the pool. He laid her in a wet puddle to fumble about at mouth-to-mouth resuscitation. That evening Syd and Max overheard him tell Mr. Radford that he was worried about Mrs. Radford, that one day her cigarette would ignite the alcohol fumes on her breath and set her on fire. Around town a discreet myth surrounded the incident for many years.

When Max was thirteen Mrs. Radford finally got the job done with pills. Max had found her wrapped in a towel on a chaise lounge beside the pool. Max phoned Dr. Radford, who was in surgery. Max and Syd hunched together in a front pew at Mrs. Radford's memorial service. The only other people in the funeral home's chapel were Max's maternal grandparents, her father, and the Albanian maid. Instead of a casket, some sort of tiered arrangement with white lilies and felt doves on florist wire rested quietly on a dais. The whole thing resembled a wedding cake. No one cried particularly except the Albanian maid who sat behind Syd and Max clicking her tongue. Before the minister arrived Shostakovich strained through hidden speakers. During the service Max 
and Syd swung their legs and communicated using an alphabet they had invented using their fingers. The peremptory minister would glance over and knit his furious brows at them. The adults present took their turn at the lectern to say a few things about Mrs. Radford. The minister said some prayers and the ceremony ended. Everyone filtered out through strains of Tchaikovsky. The following year Dr. Radford sent Max to a preparatory school in another state. For the next six years Syd only saw her when she came home on summer vacations.

Instead of attending her high school graduation, Max caught a plane to Mexico City. From there she took a bus south to Chiapas. Her correspondence with Syd was regular at first, filled with many pages that described her situation among the Zapatistas and her thoughts about it, but she never included a return address. Sometimes she sent her poems. They were mostly about truth, nature, revolution, and Mayan culture. The letters began to dwindle, and after eight months or so they ceased altogether. Even though Syd had a boyfriend, she missed Max and thought about her often. In her mind she made up stories that would explain what happened to Max but the stories always ended differently, if they ended at all.

2.

I sit at this rough table over my journal. The air is warm, but my hands are cold. Iridescent iguanas visit me here in this mud hut. Outside the window falcons soar, their enormous wingspans tipped with late sun. Children fly kites. Clouds broom the skies ahead of intermittent thunderstorms. Fog dampens great pines and mists comb cornfields. Rivulets of earthen-red rainwater carve exquisite cliffs. The highway bends for a distance 
around the mountains before moving off across the plain, toward the horizon where I can see a forest and beyond that for hundreds of kilometers it fades into faint blue mountains. I came here from el norte, a witch-work of stolen places and things, where the glare of day hides everything, where people see so much they are blind, hear so much they are deaf. Here vast thoughts loom longer than time. What sort of mind could hold on to them? And how long is now? When I lift the pen its point startles me. Imagine the damage it could inflict if I let it. A good thing I keep it wedged between my thumb and fingers. Last night I woke to a moon-flooded room and my pen wrote a couple words on a slip of paper. The words were: "I'm clever." They sounded ridiculous when I read them aloud. I don't know where words come from. I blame the pen and its unfathomable wandering. Such trivial struggles. Philosophers say humans would do better if they plumbed the voids at both ends of their lives. Once I threw rocks into one void, then the other, and listened.

My dad was never around. I rarely saw my mother eat. I was four years old the first time I remember seeing her drunk and staggering. She crumpled noiselessly on the kitchen floor. I was sobbing. After a long time she pulled herself up and fixed me cocoa and toast and held me on her lap on the sofa, stroking my hair, telling me the story about the girl who killed a cow so she could marry a green bird. It was the only story she knew. She chain-smoked and twice set herself on fire, once in bed, once on a chaise lounge by the pool. Edlira clicked her tongue a lot and doused my mother with water. The paramedics took my mother off in an ambulance. Another time Mr. Upstone found her face-down in the pool. The following summer my best friend Syd and I were splashing 
around in the shallow end one night while my mother hooked her elbow on the side of the deep end and sipped a cocktail. The glowing blue water foreshortened her legs into an amorphous blob. There were crickets out and stars. My father was away on business, as usual. I don't remember who dragged her out or who phoned emergency. I do remember the mad flash of red and blue in the trees as the paramedics got her on a stretcher. In sixth grade Syd and I pretended the kids at school couldn't touch us, couldn't hurt us.

Whenever Mrs. Wyatt sent us to Headmaster Boskell he told me to stop crying or he would put me in a room by myself. Three years later my mother swallowed a lot of pills. I found her wrapped in a towel out by the pool with her makeup smeared. Even now I see the world through a peephole gouged out by my mother. I believe that we all die lost and unhealed and confused.

The zapatismos here say it is good to be everything and nothing at once; it is good to be all at the same time gay in San Francisco, black in South Africa, Asian in Europe, Palestinian in Israel, Jewish in Germany; it is good to be an artist without paintings and a writer without readers; it is good to be in a place where the majority must shut up and listen to the minority who has found her tongue.

Some here in Chiapas have managed to shed the bonds of money like an old snakeskin. I'm still scratching it off in great flakes. They assume new forms and shapes from the inside, at first imperceptible, waiting in shadow like the darkness that gave them birth, like the jaguars, flying squirrels, monkeys and tapirs that roam the remains of cool forest outside my window where pine limbs spar in the mist. These animals sometimes enter my dreams and watch me from their hiding places, waiting their turn. The morning 
I first arrived I walked outside the hut and nearly wept at how lifelike everything was. I picked up a handful of soil and stared at it for a long time. Something came over me and I ran down the path toward the village as fast as I could, just seeing. 
Pillars ${ }^{1}$

Soho, London, 1999

If only things had not turned out so horribly, as they always did, Compol thought, he would not have been sitting on a curb in Soho with his best mate Scarfe on a bright winter's morning. But there he was with his feet in the gutter blinking through sunglasses at Berwick Street. Two women in burkas hurried past a scruffy bloke in untied sneakers who leaned from the curb and passed something through the window of a van. An octogenarian in sunglasses, flat-brimmed hat, and tarnished three-piece suit strutted past smartly with his silver-tipped cane as a Wasteaway truck rumbled along collecting rubbish from dustbins and yawning shopkeepers clattered up their louvered metal doors. Scarfe yawned loudly and Compol eyed all the sleek, multinational boutiques that were displacing this once-funky hip district.

The previous night he and Scarfe had gone on a Soho pub-crawl. The names swirled in his head: Blue Posts, Moon Under Water, Pillars of Hercules, Endurance where, between pints they worked out the rat-runs that connected Wardour, Dean, Frith and Greek streets where they argued about which road to take to what destination. Around them fluorescent signs advertised clip joints and operations where "models" plied their trade in studio flats. Someone had punched him in the glasses, knocking them to the

\footnotetext{
1 The Pillars of Hercules are the promontories that flank the entrance to the Strait of Gibraltar. The northern pillar is the Rock of Gibraltar. However, the identity of the southern pillar, a North African peak, has been disputed throughout history. The lost realm of Atlantis was believed situated beyond the pillars, which placed it in the realm of the unknown. There it is believed the words Nec plus ultra or Non plus ultra, "nothing further beyond," warned sailors and navigators to go no further. The pillars support the Spanish coat of arms, which bears the motto Plus Ultra, or "beyond." The motto encouraged Charles V, King of Spain to ignore the ancient warning, to take risks and go further beyond in his desire to view the pillars as an entrance to the rest of the world rather than as a gate to the Mediterranean Sea. One commonly held theory was that the two vertical lines on the old American dollar sign represented the Pillars of Hercules.
} 
ground and stamping them to bits. Scarfe wound up dragging him around Soho until buildings sucked the night back between their cracks and like vampires, the two of them lumbered back to their frowsy hotel room and fell comatose to bed.

A day earlier Scarfe had banged on about taking a train from North Lincolnshire to London. Travel, Scarfe assured him, healed all wounds, meaning Compol's wounds. It was all about a girl. It always was. Her name was Jolinda. And Compol replied that unlike Scarfe, who spent so much time reading books that he knew nothing about women or human relationships, he, Compol, was a real human object with real needs.

"Ah." Scarfe had leaned forward in his seat on the train and raised an exclamatory finger at Compol's nose. "And who was it just last week bleating at the sky that there was only one place we can go, around the corner in Soho, where other broken people go?"

"You're not broken."

And now, after a night of dodgy antics, Scarfe continued their train conversation as they sat on the curb. "The point is, you've gone mental over a bird who went back to her husband. It's unhealthy. What you need is a fresh outlook." He stood up and thrust that finger of his forward in the fashion of a military commander. "Plus ultra! We must take risks and go further beyond!"

With some effort Compol got up on his pins and reeled. The manky street that accosted him was like one of those raddled, smelly people you move away from on a bus. They continued through a narrow congestion of cars and delivery vans, through the early din of commerce, through odors of grease and spices and the reek of urine where buildings met sidewalks. Outside an Indian restaurant a couple pigeons picked at last night's curry thrown up on the pavement. People roamed around admiring themselves in 
windows. He rubbed his temples in a slow puncture of enthusiasm. "Let's go back to Scunthorpe tomorrow." Scunthorpe with its vistas of smokestacks and farmlands that stretched toward a tired horizon. Soho made him homesick for Scunthorpe with its four letter word in the center. He would phone his sister to drive down and get them. He rummaged in his rucksack for his mobile phone and pulled out their room's TV remote instead, which made him wonder what else he had done the previous night.

Scarfe waved his hands in disapproval. "No, no, no. We agreed you needed a variation in circumstance, remember? And so we are here, intrepid adventurers. It will be fun. After a flat white ${ }^{2}$ and a paracetamol ${ }^{3}$ you'll be a new man." He patted his jacket and produced the 1992 London guidebook — out of date and aging rapidly — he'd bought for a quid at a thrift shop. "Let's give it one more day."

"But I'm homesick."

"Don't be an ass. It's just a glandular thing," Scarfe said as he flipped through the foxed pages of the guidebook.

Compol slouched.

"Look at this." They halted in front of an art studio as Scarfe pressed a finger on one of the guidebook's grubby pages. "The Breakfast Club. 'Full monty, the works," he read. “'Bacon and eggs, pancakes, all American.' And it's just a short walk to D’Arblay Street."

Compol held his head. "Oh, god no. I couldn't face a plate of snotty eggs."

\footnotetext{
2 latte

3 aspirin
} 
Scarfe reached for his wallet to consult his money. "Right. Anyway, I'm nearly skint ${ }^{4}$ as it is." He consulted the guidebook again. "Then let's head over to the Bar Italia." "Not another pub. I know where hell is. It's at the bottom of a night's worth of pint glasses."

"Don't be ridiculous. It's not a pub. It's a café."

Compol stared biliously at a window-full of sleazy mannequins bent in suggestive sexual positions. "There are probably all sorts of things available under the counter in Soho," he said, "but I doubt breakfast is one of them. Chronic, opium, cartons of johnnies, ${ }^{5}$ more like."

"All we need is some coffee. Says here the Bar Italia serves coffee twenty-four hours a day." He walked along with his nose in the guidebook, reading aloud. "'Bar Italia is a hang-out for artists, writers, musicians, strippers, hustlers, trannies, dandies, and small-time gangsters," Something is always happening there. That's what we need." With a disturbing grin he advanced through bustling multitudes with Compol scrambling to keep up.

They crossed Wardour Street and continued on through alleyways to Dean then Frist where four burly firemen seated outside beneath a sign that said BAR ITALIA were shoveling in their breakfast. The place was nondescript save the row of Italian flags that hung over its narrow glass front entrance. Inside they discovered a shoebox of commotion: hams, flags, and soft toys that hung from the ceiling over 1950s doo-wop kitsch with red leatherette stools, chrome fittings, Formica surfaces, and a poster of

\footnotetext{
${ }^{4}$ broke

5 condoms
} 
Rocky Marciano above the bar. Auntie Beeb ${ }^{6}$ blared football scores, weather, news about Kosovo from a big-screen TV on the back wall.

Behind the bar a gent with thin white hair and a pencil-thin moustache joined his finger and thumb into the circle of perfection and said, "Tell Frankie here how you want your coffee, son. He will prepare it to your exact preference. Tell him twice and you will never have to tell him again. He will remember you and know exactly how you want your coffee, getting it right every time." The bald, brisk barista performed at a large coffee machine and delivered their espressos in small ceramic cups decorated with a artistic drawing of the café. Compol took a careful sip and considered telling the barista his preference in cities, or maybe women, to see if he remembered. They chose two stools along the Strait of Formica that ran parallel all the way to the back. Two stools down from Compol a pair of lovers sat in silence looking into each others' eyes. Next to Scarfe a portly fellow in a Windsor cap was fighting a section of The Times into shape. "Everyone here looks clean, cosmopolitan, and ordinary," Scarfe said with a deflated face. It was true. No one there looked like a stripper, hustler, or gangster. But the walls were cluttered with framed photographs, historic scenes inside the café full of strippers, hustlers, and gangsters all smiling at the camera. He got up and tossed his outdated guidebook into a dustbin near the bar.

Compol tried to ignore the lovers silhouetted against the glare of the front entrance as traffic seemed to pass through them. He was jealous of the cold coffee rings that grew around the inside of their un-drunk cups. He must have traveled to Soho for some reason, but whatever it was, he had already reached the furthermost limits of his

6 BBC news 
tolerance... or rather... Hello. Who was that down at the far end of the strait? A girl. A girl with shiny, auburn hair. Sitting by herself. A girl sitting sideways by herself between empty red leatherette stools, a white cup in her hands. At her elbow a clean white saucer that belonged to the cup. The cup in her hand. An empty stool and a clean saucer. A girl with lovely eyes that caught the light as they stared off into space.

Something wet on her cheek caught the light. The red of the leatherette stool that flew up and tinted the angles of her face. An empty saucer. A wet cheek. A white cup. Down at the end of the strait. The lovers vanished. Soho vanished. The Bar Italia vanished. Scarfe vanished. Compol's hangover vanished. He vanished. His heartbeat rose and flooded his body. She was the most beautiful creature he had ever seen. Plus ultra! Cup in hand he swung off his stool and navigated down toward the end of the strait, toward her. 


\section{The Mourner}

Funeral director seeks talented woman with desire to please. Must dress appropriately in black dress and hat with large brim. Must have large supply of handkerchiefs. Must have black umbrella without holes for rainy days at the cemetery. Must have ability to cry on demand. Must never be without handkerchief held against cheek and tears must never stop flowing. Beating on chest with both hands will encourage necessary atmosphere. Wailing while pulling out hair and falling to ground or flinging self over casket a plus, especially in ceremonies where people show little grief for the departed. Must be able to motivate a family to remind them how much they miss their loved one. Must have ready answers when asked who you are and what you are doing at service or graveside. Must have own transportation. Compensation given for long distance travel. Age not a barrier. No experience necessary. Average pay for religious service and cemetery attendance is five hundred dollars, with potential for $\$ 200$ thousand yearly. Must be willing to demonstrate skills at interview. Apply promptly in person 1 p.m. Tuesday, September 5th at Cluff's Funeral Home, 13489 East Broadmoor Ave..

The mourner had not been inside a church since she was twelve. The one she entered now sat on a wooded knoll that overlooked the city. She wore an appropriate black dress and hat and her purse was stuffed with handkerchiefs sprayed with lilac cologne to remind her of her late grandmother. Her dress, although tasteful, pulled the 
seam at every curve. The cut glass beads on her black slippers refracted afternoon light that filtered through high jeweled windows into a scattershot of prismatic spangles. The pews laid out in the shape of a cross and stained dark from a century of contact with human skin. She slid into a pew somewhat back because the etiquette pamphlet from the funeral home said it was customary to reserve the front rows for family and friends, reminding herself to act as if she belonged among them. People in black were filing in along the nave and sat fanning themselves in pews like rows of crows on wires, hushed and restless in the presence of death. Sounds from the fairgrounds midway drifted inside through the narthex and caught high in the vaulted ceiling. Nothing was private here where the faintest whisper carried and echoed like ice water inside a cave.

The closed casket on its dais was surrounded by sprays and wreathes of gladiolas, asters, lilies. A motorcycle rumbled into the parking lot, its reverberations momentarily driving out whispers and rumors and sighs inside the church. The pastor in a stark white collar and rimless glasses emerged from a door at the side of the altar to bear himself forward with resolute purpose, whereupon a matriarchal woman in a feathered hat heaved herself from her pew and caught him mid-stride for a chat. He smiled vaguely and patted her hand while his gaze wandered over the meager congregation. His gaze now came to rest on a big man as he limped down the nave in a motorcycle jacket and bandana tied around his head. The mourner imagined him on shore leave from some Viking ship down in the harbor had his right leg not been clamped in a metal brace. The matron turned to follow the pastor's stare. When she saw the Viking her face animated with delight. She beckoned him toward them and introduced him to the pastor as her nephew. He would, 
she said, be delivering the eulogy. The pastor put on a jolly and officious face and shook the Viking's hand. He asked the Viking how long his eulogy was.

The Viking said he had not timed the eulogy. He did not know there was a time limit.

A vague movement swam across the pastor's eyes like a carp in dark water as he regarded the nephew over his glasses. The eulogy should be five minutes tops, he said with a crisp sniff. Four would be better. But three ideal. Could he possibly make it three? A few of his older parishioners had already died in this heat he did not want another corpse at a funeral. So many people slept through services these days, he said, and the only thing for it was to pack 'em deep and make 'em weep.

The Viking scratched the stubble on his chin and said he would need more than four minutes. His uncle had lived a long life and besides he had worked all night on the eulogy.

The pastor leaned closer to the Viking. The mourner had to strain to hear his words and missed some at that. Something about how hot it was in the church and Emily Dickenson and the world not stopping for death. Something about time being money and whittling the eulogy down so the whole thing could be over in fifteen minutes. The matron switched her handbag to the other arm. The high colored windows reflected in her eyeglasses as she stared up at the pastor. Something about a button the pastor would press and a red light hidden on the pulpit glowing when the Viking's three minutes were up. The pastor patted the matriarch's arm with a somber nod and continued his way toward his pulpit.

The matron grabbed her nephew's arm before he could turn to find a seat. "Now 
don't you go mentioning Phil," she said in a rough whisper. "None of the relatives want to hear about Phil."

The Viking grabbed the altar rail to balance himself and rub his fingers along inside the brace. Years of wear surfaced on his face like something from the primordial deep. He opened his mouth and shut it. She shifted her handbag to the other arm again and motioned toward the uncles in the front pew. 'For Pete's sake don't blame me. I'm just their messenger," she said. "God knows I'm not against all that gaiety business."

The pastor, chin in hand and thrumming the pulpit with his fingers, was surveying the scattered faces below him. He glanced at his watch now and again. A few people still doddered in supported by others, pushed in wheelchairs, or tapping their walkers. Several had already nodded off in their pews. The last rows were populated by a modest group of younger men, shoulder-to-shoulder, some of them dabbing their eyes.

When the two front rows were nearly full, the pastor raised his hands and bestowed a blessing on the congregants before saying a few words about a son taken back into God's bosom. After a brief prayer and a few words about the deceased that could have been said about anyone he introduced the nephew who would deliver the eulogy. There was a shuffling among the pews.

The Viking climbed the steps and placed his notes on the pulpit. 'I-I'm pleased that you could all be here to say good-bye to my Uncle Henry today," he said. "He would be happy to see you all. He had a good life and he showed me how to have one. He used to bring me tins of shortbread and chocolate truffles when I was little and took me for pony rides at Getaway Lake. When I was older he taught me how to play gin rummy and cribbage. He took me to Hollywood on my twenty-first birthday. Henry loved to eat and 
cook, but he never got fat. He lived true to himself and he enjoyed his life." He stopped to regard the sweep of faces and the fanning of memorial cards, the clusters of graying heads at the back and the grayer heads at the front, especially those of the surviving brothers. "Not everyone knows how to do that." He paused again. Save bits of snoring near the front and a few coughs, only distant sounds from the midway toyed with the empty spaces beneath the vaulted ceiling. "Some would say he dug his grave with his love of life. Others would say his spirit is still here watching over us. But he would not want us to mourn for him. He would want us to love our lives." He shuffled through his notes until he found what he was looking for. "I think my uncle would agree with Matthew 6:19, 'I tell you, do not worry about your life, what you will eat or drink; or about your body, what you will wear. Is not life more important than food, and the body more important than clothes? Look at the birds of the air; they do not sow or reap or store away in barns, and yet your heavenly Father feeds them. Are you not much more valuable than they? Who of you by worrying can add a single hour to his life?"' The Viking blinked as he stared down at something on the pulpit. When he continued it was in a broken voice. "Uncle Henry would want us to love. He knew what_-" People shifted restlessly and fanned themselves more vigorously. He cleared his throat and glanced over at the pastor who was groping a button on the wall next to him. "—-love is." Those who were still listening whispered among themselves. The pastor's face had developed a rubicund hue. He stood up and smiled piously. "Well, thank you for those generous words. Now let all who can stand for the bless_-"

"AndUncleHenrylovedPhilforthirtyearsandhewouldhavewantedmetosaythat," the Viking said. A general stiffening and whispering passed over the front-most aisles like 
wind over a wheat field. There were grimaces and gurns and exchanges of eyes. The Viking grabbed his notes and hurried down from the pulpit to take his place in a front pew. A host of heads turned around to stare at a small man with elegant gray hair and black-rimmed glasses who sat by himself in a far corner of the chapel, an unassuming man the mourner guessed to be Phil, Uncle Henry's beloved. The pastor bestowed a hasty blessing under his eyebrows and ended the service which had exceeded, according to the mourner's watch, fifteen minutes. The Viking and five other pallbearers shouldered the casket outside to the hearse to the sound of fairway barkers and calliope music that drifted up from the edge of town.

The funeral entourage proceeded through a blast furnace of dry heat under a pilotlight-blue sky. The cemetery stewed in the sun, denuded except for rows of grave markers that rolled toward the horizon like streets of flat gray houses. The pallbearers positioned the casket between the grave rails on canvas straps and a few women placed floral arrangements around it. The group of younger men with Phil among them hung together by themselves a little to the side like black notches carved on a fuselage. The family sat opposite them under a canopy. Some cast odd and accusatory looks at the mourner as she took her position near the grave. She squinted back at them through her sunglasses. Her hand trembled as she raised it to square her wide-brimmed black hat.

Everyone quieted when the pastor began reading a clichéd selection from the Old Testament about ashes to ashes. He continued with a sermon about the brevity of this life and the eternal journey with the heavenly father. A few people had their handkerchiefs ready, but the rest were either dozing in metal folding chairs or gazing around at other people or off at a distance. 
Must be able to motivate a family to remind them how much they miss their

loved one. It was her cue, it was show time. She lurched toward the casket with her hands up, her face contorted with grief. A gasp rose from out of the canopy like a dole of doves as she flung herself over the smooth curved surface and beat it savagely with her fists. “Henry! Henry! O my sweet Henry!” she wailed, dislodging asters, lilies, and ferns.

She stole a glance at the pastor who had thrown his hands into the air in some kind of supplication, but neither he nor God could not deter her. She began to beat her breasts and wail more loudly, throwing herself to the ground, writhing and convulsing against it. Two men in dark suits and wires stepped behind her and grabbed her arms. They pulled her to her feet and demanded to know who she was and what she was doing there. People beneath the canopy muttered with disbelief, Who was she? Who was that woman? Make her stop.

The mourner wrenched her arms free from the suits to stand quietly dabbing her cheek with a lilac-scented handkerchief. The pastor cleared his throat and began to read again with a tinge of annoyance in his voice. The mourner waited for the suits to bow their heads and clasp their hands in front of them as if ready to swing a golf club. She threw herself against the casket again and howled like the last wolf for his pack, and again they grabbed her arms and pulled her away. Her face streamed with tears and snot. She flung her head back and howled more loudly.

The Viking limped up alongside them and asked the men to release her. They stepped back adjusting the wires in their ears. She dropped to her knees and clenched the casket handles. He bent to tell her how much he admired her style. While the preacher droned on irritably the Viking helped her to her feet. She heard a loud ripping of material 
in the vicinity of her backside. Their eyes met with some kind of recognition. He removed his motorcycle jacket and gave it to her to hide the rent in her black dress. She knotted the sleeves around her waist and, still on the job, re-applied the handkerchief to her cheek contorting her mouth into a frightening shape, letting out another wail. The pastor groaned. People stood stiffly and consulted one another. Some of them from Phil's group begun to weep and moan audibly and embrace each other. Some swept in around the mourner and knelt at the coffin to rest their foreheads against it. The matriarch came out from beneath the canopy to join other women who had been standing in the hot sun. They let their faces contort, let their arms lift and wave in the air. One by one they began to rush toward the casket where they heaved themselves to the ground and beat their breasts, tore at their clothes, and fell against each other in an orgy of grief.

Those beneath the canopy, including the brothers, looked on with horror until a few of the women broke away and tried out a few stiff facial contortions and unusual sounds. These braver women among them began to hold each other and talk to each other as if they strained to remember something.

The pastor, who had clearly had enough, raised his voice and clapped his hands. Like a judge he demanded order. He said such displays were an outrage. He reminded them that the living must conduct themselves with dignity and decorum around the deceased. But no one paid him any mind. As a last resort he bent toward the low metal frame around the grave and pressed a hidden button to lower the casket slowly into the ground. A few of those pressed to the casket lost their balance and nearly fell with it. The wailers and howlers and breast beaters began to settle their faces and body parts and collected themselves to return to their places. Composure had restored itself. The 
mourner, handkerchief still at her cheek, took refuge among Phil's friends who folded her inside like a long-lost sheep.

The pastor squared his shoulders and tossed a handful of dirt into the grave which sent back a hollow clunking sound, ancient and formidable. Others took up handfuls of dirt too and looked around as the wheels in their minds began to turn. These hesitated at first but the Viking threw in great handfuls of dirt with more force than was necessary, bellowing his grief with each throw. Others copied him and stood back arm in arm surrounding the grave. Someone began to sway and sing John Lennon's song "Love," and the others joined in. The pastor's face seemed at war somewhere between refusal and helpless astonishment.

After the song ended, the congregants dispersed toward their cars and the backhoe moved in. The Viking caught up with the mourner and complimented her for her performance. He told her he had never seen anything like it. He said he hoped she would come to his funeral. She said she doubted she would because they were about the same age and anyway he had mistaken her performance for genuine grief. She had never met his Uncle Henry. He said his uncle would have loved her show and her for performing it. He said she could keep his jacket in exchange for her address. She hesitated. He asked her if she would like to ride on his motorcycle to the fair where he would treat her to a ride on the Ferris wheel and some deep-fried butter on a stick. When they reached his motorcycle, he gave her his helmet. He towered over her and, except for his leg brace, he could have been looking out over gray waters from the bow of a mighty ship. 
Goldfish

I came home late in a cab all by myself, chauffeured solo across Manhattan in a fabulous red dress and caught a glimpse of what my life might have been like if I had left my husband three years earlier instead of sitting on the sofa glaring at him while he played with the dog. Three years of my life without a glimpse. But I had reached the age of thirty-five where once every three years a glimpse was enough.

That night I lay awake and talked to my mother who had been dead for five years. When I finished talking to my mother, I began to talk to myself, remembering what I had forgotten to do during the day and planned what I would not do again the following day including Mt. Laundry, which awaited me in the basement. My muscles had stiffened to planks. I told myself to relax and stared at the shadows on the ceiling but I could not find any kind of shape or meaning in them, so I began to calculate how much sleep I would get if I fell asleep at that moment. I went on calculating deep into the night, and in the process I realized that I did not want to sleep alone as much as I did not want to listen to someone snoring beside me in bed.

When I phoned Natalie we caught up ten years in a half an hour. We had been best friends in high school. After I moved east we corresponded now and then. In those ten years I sold lofts and condos to incredibly rich people while she and her husband Silas had traveled to countries like Iraq and Afghanistan. Silas worked as a photographer for a news magazine while she volunteered as a therapist with Puppets for Peace, which helped traumatized children by using puppets. The last part of our conversation involved her 
persuading me to move back to our hometown where she still lived. I agreed with fake reluctance, wanting her to believe that I would be sacrificing a full and exciting life.

The move back was pretty simple, a matter of packing a few suitcases and donating the rest of my possessions to charity shops. It felt good to be free of them. I drove through six states and got a room at the Holiday Inn the where I slept late into the next day. I stepped outside to take in an afternoon view of the Rockies and aspens and breathed the mountain air. Lime-green leaf buds studded black branches and the harsh cheer-cheerful call of a bluebird echoed through cool, early shadows combed with sunlight. Everything glittered with raindrops. I hardly recognized the town now. Colossal new houses lined corporately antiseptic streets and old neighborhoods had vanished and gone vertical, rife with sleek, multinational brand names. I slid on my gray wool dress and drove to Natalie's house.

Natalie and Silas still lived on the tree-lined street in the same bungalow I had shown them shortly before I moved to New York. She was a marriage, family, and child counselor who weighed more, smoked more, and worried more than I did, even though in high school she had been voted most likely to be a model. Their 1913 bungalow had once been featured in Architectural Digest. We sat out on the veranda in white wicker chairs and nibbled strawberry pie that had come in a pink bakery box. Across the street in a park children squealed and shouted as they played on playground equipment. I remembered my own childhood, cooped up all winter and released in spring. Natalie helped herself to a second slice of pie before I had finished my first. It was inevitable that our conversation veered towards my failed marriage. I did not tell her that one reason I had moved to New York was to avoid gossip in a small town. I did tell her how I blamed my relationship 
problems on my fear of mouth kissing, especially tongue kissing. I told her I might become a prostitute because I thought I could make better money as a prostitute than as a real estate broker. Besides, I had heard that there was some kind of rule that I could refuse to let my tricks kiss me on the mouth.

Natalie said she'd forgotten how boys never got to first base with me in high school, and now she knew why. She asked me what my problem was. I asked her why she always turned my dating issues into clinical discussions. She asked me how old I was when I first became aware of my problem and what was going on in my life at the time. She had this annoying habit of nailing me to my private shortcomings. I told her that marriage had cured me of dating, so I no longer considered kissing a problem. Besides, I said, I had never understood the purpose or concept of kissing. I wanted to know what was so great about it, why everybody was so crazy about it. I wanted to know when and where the whole thing about exchanging saliva with another person had started.

She said she had never met anyone who disliked kissing. At any rate, she said, she was not interested in the history of kissing except that she believed it was a fairly recent yet universal human expression of sexual, parental, or filial love and affection. Kissing, she said, involved the mother of the senses, touch. Kissing on a romantic first date, for example, flooded the brain with dopamine, a pleasure similar to what happened when a person took cocaine. At any rate it I was to keep the conversation specific to my own experience. Moreover, she said as she pressed her fork onto her plate to adhere a few sticky red crumbs, we really ought to be addressing my aversion to what was otherwise an extremely pleasurable and healthy activity. 
I was certain that facts that were true for others were not true for me. I had been an only child of parents who had adopted me late in their life. They always kissed me stiffly on the lips to say good-night or good-bye while all of my friends' parents kissed them on the cheek, the nose, or the forehead, but never on the lips. Even as a child I had suspected that my parents' kisses were incestuous, although incestuous was not a concept I would have known at the time and was it possible to be incestuous with an adopted child? I could not be sure.

I told Natalie about the obligatory spit baths my grandmother gave me on long car trips from Wyoming to Colorado. She performed these by sitting me on her lap and scrutinizing my face, arms, and legs. She could not see very well, but when she thought she had found a smudge she would blot a white handkerchief on her tongue and dedicate herself to rubbing it until she was satisfied it had disappeared. Her work would leave red marks and a fecal odor on my skin.

Whenever I went to a movie on a date I turned my head when two actors began to kiss. And afterwards when my date would try to kiss me I also turned my had. But the incident that sealed my fate was during my ninth summer when my parents reserved the same campsite every year up in the Rockies. They parked their Deville travel trailer beside a creek among aspens and cottonwoods. My bed was always on the fold-out canvas cot slung between two rails above the double bed at the rear of the trailer.

One afternoon my parents began to drink with a bunch of other adults. A city of half-gallon liquor bottles cluttered the wooden camp table. There was a reeling ramp-up of revelry until way past midnight. I fell asleep despite all the raucous and sloppy conversation. Sometime in the night the quaking trailer awakened me along with a racket 
below. I cautiously pulled back the edge of the canvas under my pillow, away from the wall, and peered down at the bed. Something, a hideous paralysis, clutched my throat. There I was above my parents inside a quaking fishbowl. Whirl-a-tilt stars exploded over my vision. There was my mother lying on top of my father rhythmically rocking the trailer and making sounds that I could not associate with a mother who owned a silver tea set and books on British royalty, and who taught cotillion classes. I had heard about what she was actually doing from schoolmates. They called it having sex. And if you were over forty and had sex they called it Jurassic schlong. In my mind I threw myself from the cot with a quick bound and leap out the door, but in my haste to escape, my leg caught in the sleeping bag, which had gotten wedged between the wall and the cot's support frame. I yanked my foot until the sleeping bag gave way with such violent force that it sent me careening down on top of my parents. In the years that followed they never mentioned the incident, but I held on to my virginity until I was twenty-nine.

I see, Natalie said like a marriage, child, and family counselor. She let loose a bray of laughter. When she had composed herself she said she was ashamed of me, and reminded me that children suffered every day around the world and often perished from abuse and rape and other terrible side effects they could never escape either. She enunciated slowly, to make certain I understood. But theirs was trauma, she said, while mine was a simple coming-of-age experience. I imagined myself a curve of faded fish cadaver floating in a bowl, one betrayed eye gawking the air the other the water. She had this habit of calling attention to her practical wisdom and intellectual superiority. I wanted to tell her that after falling on my parents that night it seemed as if a different 
family had rented my body and from then on all I did was move around with them inside me, but I knew she would not understand.

She gathered our plates and forks and said to wait there, she wanted to show me something and disappeared into the house. Across the street in the park children played and rainbows arced over sprinklers that whisked and whirred, sending sparkling plumes of water. Automatic sprinklers in the park were set to operate from spring through fall, even when it rained. When Natalie returned she handed me a photograph Silas had taken. She explained that it was of a bombed-out house in Afghanistan. Only one wall and its second floor were still intact. An old woman sat in a chair on the second floor amidst heaps of rubble. Her face was charred and streaked with blood and fine white dust. Her eyes, unfathomable as dark wells, stared out over a landscape of bodies in the street, over ruins that had once been her village. Beside her, on a chest of drawers, an alarm clock had stopped at one twenty something. Natalie said the woman had lost her entire family in the bombing. We gazed out at the park and the children and over the trees and rooftops at the Flatirons, a set of rocks that leaned against the foothills like enormous ironing boards. When I turned to say something, her eyes had softened, as if they searched for something coiled within themselves, an expression I had seen on other child-less women. We sat like that for awhile as the happy children shrieked and cheered across the street. Silas, she said, had given up photography. He could no longer look through a camera lens without seeing dead children in it. She said I was to keep the photograph, to carry it with me to look at whenever I felt that life had dealt me an unfair blow.

I ended up renting an apartment across town. I hung my clothes in the closet and went out and bought a sofa bed and a French press and some flowers. That night I met up 
with a few old friends. We ordered pizza and played board games. A few nights later the family inside me fought while I lay on the sofa bed trying to relax. My phone rang. It was Blake who said he called to say he thought I was so damn beautiful and that he'd always had a secret crush on me. I pulled out the photo of the old Afghan woman and stared at it. Finally I said, Oh yeah? Then why am I eating goldfish in bed alone on a Saturday night? 
Panic Attack

Look out the bedroom window at the house across the street for the fourth time this morning. The curtains are open in the house across the street. The blue car is parked in the carport. Someone is home over there. Tree bones and clouds stew in the muddy potholes between your house and that house. Canada geese honk over the rooftops in a regimented V. After the honking fades the only sound is the ceaseless rush of distant traffic. Everyone in the neighborhood who still has work has gone somewhere to do it.

Glide into the kitchen for your fourth cup of coffee. Tell yourself the caffeine distracts you from the situation across the street. Cross back into the living room. Sit on the sofa with your coffee and flick through the vacuous glut of television stations. Pretend to watch the morning news. Ignore the corner of your writing desk in the next room. Tell your desk you will be there in a minute. Tell yourself that the morning news is informative and important. Tell yourself the world situation isn't as bad as the morning news makes it sound.

Ignore the perfusion of dread, despair, and disillusionment through internal channels induced by the large government debt you incurred for classes that you convinced yourself would open doors to a livelihood. Ignore that sensation of drowning whenever you dwell on the fact that your unemployment benefits ended three months ago. Tell yourself you can explain that five-year gap on your resume to anyone willing to listen. Say you will defend your degree the next time your ex says, That's what you got 
for twenty-two grand? Tell yourself you are still young enough to be taken seriously and to be considered for employment. Ignore those odd, tingling sensations in your tongue, face, chest. Tell yourself you are too young for a heart attack. 
The Street

As they drove down a crappy boulevard crammed with cars that spewed exhaust and desperation, where arthritic trees choked from dust and disease, he spoke eleven words that changed everything.

All around and everywhere the world's grief was visible, more dire than it had ever been. Yet the two of them had not argued at all that day. They were on the best of terms, all things considered. She might have had a bit of a temper problem, it was true. But despite the insignificant tantrum that bled from her that morning over coffee and crullers, a hemorrhage she staunched at once, he seemed relaxed and in a good mood as he drove. Which meant she did not expect those eleven words of his that filled the car like exhaust fumes, words that leaked from a basement of issues he had been thinking about, possibly stored down there for a long time. He said, "If it weren't for me you'd be out on the street."

Wasted people, filthy buildings, and the muted squalor of a post-industrial city blurred past. He went on driving and talking of other things, hurling the two of them through space. But she had stopped listening. Instead, she stared out the window and performed a verbal autopsy on the echo inside her head. If it weren't for me you'd be out on the street.

"If" was a conditional word, a threat, a possibility that dangled over her like a noose. It left her clinging to the random chance that her life had always been, that she was alive, teetering with the knowledge that she could as easily not be. 
"It" was a sketch of their lives colored in for twenty years by a marriage and two children, twenty years reduced to two letters remembered differently by each of them, perspectives that involved her work as a mother and his work as earner of income, the one who kept their bank account above a zero balance that allowed them to continue within the bounds of their social roles.

"Weren't," a contraction of "were" and "not," contained mutually exclusive terms, to be or not to be, to remain in place or to step out into the darkness.

In contrast, "for" was full of generosity and support, its vowel round and feminine and eternal, the give and take of life, except that it had a spigot he could turn off if he chose.

"Me" was the speaker of the sentence, the word the rest of the sentence revolved around, the active doer, the observer, the judge, the one to be acknowledged.

"You'd," also a contraction, was a threat that things teetered on change. "You would" was a conditional state of existence as opposed to "you are," which seemed more certain.

"Be" carried a whiff of permanence except that her identity existed in relation to his, a relative distance from the epicenter of his life. To be with him or not to be with him was the question.

"Out" was an exclusionary term, like a gated community. "Out" as opposed to the inclusionary "in." "Out" had nothing to do with the wage-free work she had done for so long "in," where she raised children, cooked the meals, did laundry, cleaned, and in general sustained the family home. Unlike hers, his work had monetary value in the marketplace, which made her expendable and in a position of possible expulsion, even 
though she had a Master's degree while he had only a Bachelor's degree. But because the world had moved on without her during those twenty years she would have difficulty finding work in the marketplace, despite her education.

"On," another two-letter word that included the ideas of surface and wandering over it but never a part of it, where sleeping, loitering, and surviving were conditional, even criminal, taking place on landscapes designated as public, that is, as maintained by taxes as opposed to "in" or "inside," as inside a private residence maintained by the wages of the those who lived in it.

"The street" as opposed to "a street" was specific and designated with its hoards of disenfranchised and unwashed folk who clung to the fringes of the social fabric, who dared death daily, harassed by police, those who knew what it was to be locked behind bars for having done things to survive, that rarely hurt anyone.

He parked the car in a supermarket lot. He said he only wanted to buy a few things, some eggs and shaving cream. She said she would wait for him in the car. After he left, a cold wind blew inside the car through his open window. She rolled up the window.

Rickety old people pushed grocery carts to their cars and young people sauntered past consulting their phones. There were no trees and no birds anywhere. A tribal chief had once told her that when creatures faced extinction they would go into hiding. They would go underground, make themselves invisible to humans until it's safe to come out again. It seemed to her that they had given up long ago and would not be back.

A muted scream rang out across the parking lot and through the closed car windows. The scream had come from a sport utility vehicle that faced the street. In the 
driver's seat a brown-skinned woman struggled against a man in the back seat who had locked his arm around her neck in a choke-hold. The woman managed to release herself and screamed again. She tossed a sheaf of papers out of the window. The papers blew out over the parking lot and into the busy street in a rush of confusion, whirled beneath tires, and swept in updrafts across the hoods of cars. Her face was a latitude of hatred and rage. She opened the door, but the man grabbed the door frame and slammed it closed to resume his hold on her. People in the parking lot stopped what they were doing long enough to pinpoint the commotion, and, being only what they could be, continued on to load their groceries and talk on their phones.

She understood the commanding oppression that pressed the woman's physical body against the man with the seat between them even as she struggled to burst from the car. It was the same oppression that pinned her own physical body against the car seat even as she longed to rush across the parking lot toward the van, to do something, anything, to help the woman escape. The trash, the oil stains on the asphalt, the drab beige color that violated every view from every window offered her nothing. Her violent heartbeat cudgeled soft and secretive tissues; her hand trembled, her teeth chattered as she grabbed the door handle and broke free from the car. She kept her head down even as her legs careened with a will of their own toward the van. Halfway there she braced herself, told herself to refuse all threats against her. But when she looked up again the van had gone. It had driven away as she struggled with herself in the car.

She shivered from a chill wind that found its way beneath her thin jacket. Alone on that huge section of parking lot, blinded by dullness and deafened by the endless pant of traffic in an ever-changing, temporary landscape, she began to collect the woman's 
wind-scattered pages, which turned out to be documents on divorce proceedings. A few dozen feet from where she stood, twin strips of yellow paint divided two lanes of oncoming traffic. They were nothing more than an imaginary barrier that kept cars on either side from crashing into each other. 
Thresholds

We were swimming naked in Lake Orion the night I broke up with my boyfriend, out of fear, I suppose, that he might suddenly break up with me. This threat was constant. It loomed like the dark lake flecked with torn, moonlit clouds. As we walked back to town he said it was probably good for us to break up because I reminded him too much of one of his relatives. He said I needed to relax more, that I lived, no, he used the word existed. That I existed too much in between things. He said that what he needed was a roomy, comfortable girl, and that what I needed was to deal with the tears inside me. Tears. He pronounced the word to mean torn things inside me, but as I write the word I see it could as easily mean teardrops.

I live alone now. My house is an old shack that slopes and sags. It sits on a large piece of property nearly hidden by feral fruit trees, shrubbery, and vines. Moss and fungi are slowly breaking it all down, returning it to a memory of forest that once surrounded it. In the fall when leaves and twigs blow inside, I tell myself that it is the forest trying to take itself back. In the spring I find black and yellow bumblebee bodies on my windowsill and add them to the others I keep in a glass salt shaker: a tiny museum of perfect bee husks. Their bodies desiccate but do not decay.

A for sale sign appeared on the empty house next door. I planted a row of bushes on my side of the property line, for protection, in case someone moves in. When the remote control went missing I turned the television around to face the wall. Stacks of books line the walls of my living room like a sandbags around a trench. I do not own a microwave. I cancelled my Internet account. My life is filled with friends that roam the 
pages of books, not screens. My house would be too crowded with another person. But I sometimes think having a roommate might be a good business arrangement. If I ever did take a roommate, I would insist that person agreed in writing not to talk to me. If the roommate did talk to me, it would be an easy eviction for breach of contract. The ideal roommate would have no interest in social relationships. We would both live rich fantasy lives and hardly know the other was there.

My couch is deep and short like an unkempt nest, too short to stretch out on comfortably. A deep, short couch discourages other people from settling on it. I tell myself that my couch is the reason no one stops by anymore. Isolation. I hardly know whether to mourn or celebrate. Sometimes I talk to myself for long stretches of time, either from bursts of adrenaline or from false beliefs, such as the belief that talking continuously will prevent death. My life was once filled with people with screen names and their conversations, directions that would have lead to commitment in the real world. But in the real world I avoid eye contact whenever possible.

When people stopped calling me, my cell phone became an expensive alarm clock. I turned it off for good and did not renew my contract. At any rate, the only people who called me were my manager at the insurance company and my brother. I had a lowlevel job selling life insurance. The company did not provide leads, so I spent my days in a windowless room making cold calls. I shared the room with a guy who stuttered. He also had sinus problems. The company had hired me a week before hiring him. As I listened to him work to articulate his sales pitch on calls, my whole body tensed in its effort to help him get words out. It was exhausting. Between calls I sent out loads of blank emails. Every night I left the building without saying good-bye to anyone. Saying 
good-bye to people on phones is about as useful as saying god bless them whenever they sneezed. I did not return from lunch break one day until a week later to pick up my paycheck. The manager said they had been trying to reach me. I did not tell him I had ignored their calls. I told him I had to quit in order to take care of my sick mother who could afford neither life or health insurance. I told myself a lot of people either died or lied to get out of jobs like that.

Everything continues until it doesn't. When I was six and playing with toys in my bedroom, I felt safe knowing my mother was in another room of the house. The day came when I looked for her but could not find her in any room. Yet traces of her remained: an arabesque of black hair on the white porcelain tub; the smell of her face powder on the mirror; the window shutters that she closed each night before tucking me in. But I could not find her. Mornings I would listen for her at the kitchen table where oatmeal steamed in a blue and white bowl with ALL GONE written at the bottom. The table was spare and white and things set on it made hollow sounds. But the only sounds each morning were my father's footfalls and the ticking of the clock. I waited for her. She did not step back in through the door that led out to the garden. She did not step back through in a flood of sunlight, wind, and leaves, laughing and lucent with gardenias spilling from her hands. No one could tell me where she had gone. Even now, in my adult mind, I wait for her at that spare kitchen table.

While I worked at the insurance company I lived in an apartment and kept my curtains closed. When it was time to take out the trash I would peek outside to make sure 
no one was out there. If someone was out there I had to wait until the person was gone. I never answered my door and took long walks late at night. After midnight once I woke to the sound of shouting and banging on my door. The racket terrified me. I pulled the covers over my head and waited for it to stop. I turned on the six o'clock news. A television crew had gathered in front of what I recognized to be my apartment building. A reporter stared at the camera with a troubled expression and said that an elderly woman in apartment number 27 had phoned 911, but she had died before the emergency medical technicians could find her. It took me a moment to realize hers was the apartment next to mine.

A month after I left my job at the insurance company I found an envelope in my mailbox. It was from the guy who had shared my room at work, who stuttered on his cold calls. He invited me to eat a Thanksgiving dinner at his parents' place near the beach. To make sure I did not get lost, he came to pick me up. He drove his parents' station wagon and apologized for blowing his nose a lot. He said he had a cold. When we arrived he introduced himself to his roomfuls of family and his parents friends. His father and assorted men filled the living room. They were already pretty far gone on beer and gin, roaring over a football game. His mother was one of those people I have always admired who manages everything perfectly and remains calm and puts people at ease. She acted as if she had known me forever and called me darling, without the "g." The air was close and the house smelled gamey with turkey. The louder the chatter and noise grew, the more I felt like a stranger, the more I planned my escape. The first chance I got, when my old office mate had his back to me, I edged toward the crowded kitchen where women leaned against things with wine coolers in their hands, and slipped out the back door. 
Outside, a frail green sunset silhouetted the trees and rooftops and just beyond the railroad tracks the ocean sighed. The sound had a measured and soothing effect. I passed working-class houses where people ate and argued and watched a football game behind bright windows. In the dusk cones of streetlight tinted the sidewalks orange. When I got to the beach my legs lost their will to carry me. I could not return to the dinner and I could not continue to the beach. Home was not here nor there. It didn't seem to be anywhere. I sat down on a large rock. The sound of the waves flooded me with thoughts of my mother and other people I had lost, flooded me with the incessant loneliness inside everyone I had ever met, with the incessant whisper inside me to go home, loneliness like the sound that is coiled inside the pink inner ear of a sea shell. In another time and place my mother had told my father one night that she needed to be alone and get some air, that she needed to think a little and walk along the beach. My father learned the truth later, and I much later, that she must have strolled over the sand toward the breakers and kept going until she stepped over the loneliest threshold in the world.

I watched a couple ambling arm-in-arm, silhouetted by the deep purple dusk along the water's edge. Two small children chased each other around their legs and a setter gamboled through tongues of seawater that lapped the sand. The breeze had gone cold. I got up off the rock. Suddenly I longed to return to other people's Thanksgiving dinner where I was both stranger and guest. Somehow I could find my way back into their bright, warm, crowded kitchen. 


\section{Hunters}

For six years Fay and Arturo had convinced themselves that their situation was temporary. They lived in two rooms at the Imperial Palms, a colossal apartment complex on Inglewood's Century Boulevard between the 405 and the Hollywood Park racetrack, the artery that mainlines LAX to East LA. Fay worked in Laundromats and cheap motels and Arturo in adult video stores and carwashes. They muttered in their sleep. They sang in the dark. They carried their only light bulb between their two rooms.

For six years they had hunted and come home broken windows, jumbles of frayed drapes. They had become faded stars on chipped linoleum, cracked sinks and leaking faucets. Their top-floor apartment overlooked a litter-strewn courtyard, up three flights of concrete stairs where a torment of quarreling and babies' cries competed with the scream of passenger jets that cleared the roof by a few hundred feet on descent to LAX, frequent and punctual, day and night. The perpetual racket raped their privacy, eroded their thoughts. As they slept roaches dropped from the ceiling to scurry along blanket runnels and scuttle through the veins of their dreams.

The view through their front window was of two charred doorways. The tenants, unable make rent, set fire to their apartments and vanished. There was at least one charred doorway on every level of the complex. Fire trucks would arrive in the night with sirens, flashing lights, and powerful plumes of water. Three of the current tenants, two women and a man who all lived in 341, conducted business along hallways above the 
neglected courtyard. One of the two women, an Amazon with muscular arms and stunning bone structure, loved a Russian junkie in 428 . They had come to know the laws and language of the complex and the shape of the bones and sinews that held it together. It was where they lived, but it was not their home. They traveled long distances to hunt, although they were no longer sure what it was they hunted for.

The night they closed down The Liquid Theater Arturo lost his job. In the morning they agreed it was time to go hunting again. Fay had the day off. She was sitting at the window spooning cornflakes and milk towards her face and scanning the rental ads. There was a showing in Hollywood that day. Even if they had managed to save enough money, they would have needed three jobs each to afford the rent. But they needed a change of scene, a small vacation. It was an hour's trip north by bus. She wrote the address on a scrap of paper and they walked two blocks through the uproar of Century Boulevard to the bus stop. The sky was a bowl of depthless muffled felt, a saturation of yellow-gray light, a soup of fumes. Everywhere cracks in concrete threw up pale weeds. It never rained in LA. They caught the bus to Hollywood Boulevard with its turreted apartment buildings and thirty-foot palms, trunks like arching flagpoles. East of La Brea they got off the bus along the foothills and climbed steep tree-lined sidewalks. They had hunted in Hollywood many times and identified a neighborhood's wealth by the density of its trees. By then most of the shabby old mansions of Hollywood' heyday had been remodeled with state-of-the-art design. The address led them to a faded Tudor surrounded by a metal fence tipped with arrows. Behind the fence a flock of people pecked through the yard where they ducked under low branches and cast speculative squints at upper windows already gilded orange by late afternoon sun. The house had a 
pitched roof, an arched picture window, and striped awnings. Rust-colored sycamore leaves crunched beneath their feet as they made their way up steps to a curved oak door.

Inside, a woman with enormous eyebrows and a brimmed blue hat was handing out applications and answers. She said she represented a man who lived in Corfu. The old lady who had owned the place had left him her estate when she died. Viewers gawked at the capacious front room with its art deco fireplace and walnut stairs that curved gracefully toward upper rooms. They all circled around the rooms smelling each other with their eyes, wondering who would qualify for this rental. Who would get the stained and odorous carpets, the worn paint, the sagging baseboards. Who would get the worn skin and sinew, the hollow tarnished bones. They all scanned the yellowed wallpaper, creaked up and down stairways, opened doors to rooms inside of rooms. They all gripped the black and tacky stair railings. They inspected the kitchen where mouse turds piled like dirty rice in a recessed soap dish above the sink. They In the basement framed photos and paintings leaned against each other along the wall. A brown paper bag stuffed with photographs, as private and universal as undergarments, had spilled bits of deckle-edged, monochrome memories: a spot of duck pond, hands twisting a lace handkerchief, the edge of a sailor's hat, a baby's face.

Back in the room with the art deco fireplace a steady stream of new bodies wandered in through the curved front door. Outside on the steps people sat like spectators on stadium seats filling out the rental application. They would need three pieces of identification, social security number, work history, rental history, a credit check, a background check, a drug test, first and last month's rent, a cleaning deposit, three references, and a security deposit. Luckily for the mice no pets were allowed. The 
woman with enormous eyebrows warned the applicants that the owner would make his decision in two weeks and would require twenty-four-hour access.

Fay and Arturo threaded down the steps through the applicants, down the walkway, and out the front gate. They walked the four blocks back to the bus stop. It was going on five o'clock. Shadows pooled around a four-hundred-and-sixty-eight-squaremile parking lot cleverly disguised as a city. While they stood on Hollywood Boulevard waiting for the bus, a man in an expensive suit staggered along the gutter and fell into it. He struggled to stand, and fell again. People hurried past nervously, fussing with their cell phones. A passing man in a clown suit and enormous shoes stopped to say something to Arturo in a foreign language, gesturing to the man in the gutter. Arturo helped him drag the man to the bus bench. They propped him up and arranged his legs. He folded slowly forward until his head rested between his knees, until the tips of his hair brushed his loafers, until he seemed to be searching for something beneath his seat, and the clown continued his flop-shoed way down the boulevard. The bus arrived. Fay and Arturo got transfers back to Inglewood. All seats were taken as well as most of the standing room in the aisle where people grasped stanchions and metal poles. The passengers made themselves smaller and pushed further back to let Fay and Arturo in. The bus took off again, only to stop for more passengers, to squeeze them in, all of them fleeting and spectral, flags floating on water.

A wasted old man trembled in a seat beside Arturo. He smelled of rank tobacco and coughed over his stained clothes. Despite the cramped quarters, after several miles, he stood up and sat down and did it all again. "Oh, shit," he said, his voice graveled and phlegm-addled, "I crapped my fucking pants." A smell wafted up into the aisle. Several 
people yanked the cord for the next stop. The driver, a middle-aged man with features that looked as if an eraser had been at them, brought the bus to a halt. The doors opened with a gasp and a mass exodus burst through them, including the old man himself. Only diehards like Fay and Arturo who had miles to go remained, and they all moved to the back of the bus until the smell calmed down.

Banks of rose-colored clouds swept a deep purple sky. Seagulls flew west beneath the clouds, their white bellies tinged with the neon lights that ricocheted through the bus windows. The bus kept collecting passengers and releasing them, and smells of food blew in and out like invisible silk—Chinese, Italian, Indian. The driver pulled the bus in front of some steps that led up from the sidewalk to nowhere. It was not an official stop. Passengers sat up, suddenly interested. The driver pushed the doors open, got out, and headed toward a shabby, barefoot man who sat by himself on the steps. The man's hair stuck out of a baseball cap and the side of his face had gone missing, the whole of his tongue exposed with his nose folding into it. The eye above protruded sideways and drifted toward the ear. The driver bent to say something to the man and the man said something up to him. The driver sat down next to him and untied his shoes, slipped them off, and handed them over. The man's mouth widened so that everything beneath his nose disappeared into the hole. His city eyes reorganized into a holy, shining light as he hooked his fingers like two beaks inside the heels of the shoes and stared after the driver, as if he were afraid he might break the spell. The driver climbed back on the bus in his stocking feet. He addressed the passengers saying that he had seen the barefoot man every day on his route for years, had even given him a name, St. John of the Steps. He said he had always wanted to give the guy his shoes, even if they were the wrong size, 
only he had been afraid to pull up to an unofficial stop for fear of losing his job. He took his seat and sucked the doors shut. The riders, hushed and puzzled, sat stiffly, their eyes darting about as the driver steered back into traffic.

For six years Fay and Arturo had convinced themselves that their situation was temporary. They got off at their stop on Century Boulevard and returned to their apartment. As they unlocked the door they looked up at a screaming jetliner where a row of tense little heads were locked in descent behind bright windows. 
The Tobacconist

The tobacconist had not had a customer all afternoon. Flies crawled over the spicy bundles of brown tobacco leaves that hung from the ceiling of her shop, which was no bigger than a closet. The big brass table scale she used to weigh tobacco for Turks, Russians, and Egyptians stood vacant. She sat in a rheumatic chair among stacks of empty shipping crates and fanned herself with a folded copy of Le Monde. Its headlines read: ALGER A BARRICADÉ, L'INSURRECTION COMMENCE. Bombing campaigns were always bad for business. Earlier that morning Salazar the smuggler told her he was feeling nervous that the military might soon barricade Oran. "There are no checks for such anarchies," he said. "You cannot put them on trial after they bring such suffering and annihilate huge populations. They kill but are exempt from death themselves."

The truth was that riots had already spread to Oran and the sound of gunfire from nearby districts intensified in the summer heat. Death tolls grew daily. The colons that felt betrayed by De Gaulle were shooting rioters, and those like herself were fleeing Algeria, after having lived there for generations. Many were burning their possessions before they left.

She closed shop early. The little stray dog she had befriended trotted along beside her as she hurried down the Rue Curie to Ghaouli Abdelkader, the wide road that passed the Christian cemetery. Bougainvillea erupted over sun-splashed walls. As a non-Muslim, she wore a modest skirt and a blouse instead of a haik, so that her exceptional beauty was visible to all. She would often feel French soldiers following her with their eyes. Aziz used to encourage her to write poetry, to express her growing sense of intrusion and 
displacement. She often told him she loved Algeria but those like herself were nothing more than thieves. Under her arm she carried her father's tattered Morillon ledger where she wrote down her poems. She passed an Arab man as he urinated in a deep-cut gutter that flowed perpetually. Several yards down a toothless young woman, two gaunt children clinging to her haik, had knelt over the gutter to wash a tin bowl.

She caught a bus to the Cathedral Sacré Coeur where she took a seat on the broad steps and opened her ledger. Nowhere in Oran did she feel her anger more against the colonizers, against her own, than on these steps. Along the narrow streets below, in the long blue shadows of colonial buildings, vendors were dismantling their stalls and crates of figs, dates, pistachios, mint. Expanding and folding in great numbers over the city starlings swept the incandescent sunset with wings of orange light. The cathedral's Angelus bell pealed over the rooftops. A fashionable woman with a little boy in shorts passed her as they climbed the steps toward mass. The woman wore an elegant black hat and gloves and her chin was set with determination. The tobacconist said to her as she passed, "Are you teaching him to obey or to question, Madame?" The woman paused a moment to stare down at her. A disruption crossed the woman's face in the shadow of her hat. But she lifted her chin, collecting herself as she continued up the steps pulling the boy after her.

The little dog curled at her feet re-settled its head on its paws. The tobacconist began to write down a poem she had kept in her head. In the distance black smoke curled over the harbor against Djebel Murdjadjo, the mountain with its Spanish fortress, which towered above the Gulf of Oran to the west of the city. During her engagement to Aziz she had taught herself to be a strong swimmer at the foot of that mountain. Aziz had 
never learned how to swim - he was afraid of the water-but he would sit every day on the rocks and watch her for hours. They had married despite her father's protests. Catholic girls and Muslim men do not mix, he said.

She and the little dog scrambled beneath the cathedral's porch as a summer squall blew in from the Mediterranean. It quelled the dust and left a wake of bruised clouds. Pools of madder, saffron, and lapis lazuli ran together on wet streets as the sun sank behind Djebel Murdjadjo. She descended the wet cathedral steps with the dog at her heels, passing a beggar who sat on an upturned bucket in the murk of the cathedral. His sunken eyes were crusted shut. He demanded nothing of anyone. She found a franc in her pocket and pressed it into his hand.

She caught the bus back to her district, past miles of boarded shops and cafes. Ten paces from her tobacco shop she entered a doorway and followed the flight of stairs that led up to the apartment she shared with Aziz. Inside, every shutter had been closed to keep out the heat, and a lazy ceiling fan circulated tobacco smoke and anise. In the dim kitchen light Aziz was seated at the table, stripped to the waist. A cigarette was confined between his two fingers. Its blue swirl of smoke entwined a pitcher of water, a bottle of araq, and a filmy glass. Before the bombing campaigns began he had fought with the guerrillas in the first wave of the Thawra Jazä 'irìya, against French colonization. The bullet he took in his shoulder blade was too close to an artery to be removed. And now, nearly a year later, he still slept with his shoes on. He had taken a liking to the distilled anise drink and saw no reason to stop liking it, liked it so much he had given up working in the tobacco shop or anywhere else. He had begun to prefer it over his pledge to flight 
colonial rule, begun, even, to prefer it over her. She did not know if the bullet had caused his drinking or if the drinking had caused the bullet to rot inside him.

The little dog trotted in behind her and she closed the door. He poured himself another glass of araq and water from the pitcher swirled it milky white. In French he demanded to know where she had been all afternoon. His first language was French, but he had learned to speak Arabic in prison. "That smuggler Salazar had been up here asking for you again," he said with his gaze clamped on her.

Casually she slid the ledger in a desk drawer and leaned against the desk. "He is just a harmless little man, Aziz. He thinks I'm pro-De Gaulle. He does not even know my name." When her husband had been drinking, she sometimes chattered idly to distract him. "Last week I told him about the guard who surprised a group of armed men who were trying to wreck a power transformer and they shot him dead. I said if they clapped all that scum in jail the rest of us could breathe more freely. He told his landlady what I said and she told him I was a holy terror." She laughed carelessly.

Aziz stabbed his cigarette out on a saucer. "Every afternoon you close the shop and bring me nothing but trouble and shame." He got up from the table and moved toward her. "Every man in the city wants to get you pregnant." He loomed over her now. “And I know you encourage them.” His breath reeked of anise and spring onions. She backed away from him. The little dog darted behind the desk.

He yanked open the drawer, pulled out the ledger, and riffled its pages. "Where do you go afternoons?" he asked as he tore out pages in a flurry of falling paper. When she rushed toward him he shoved her with such force that she careened backward, knocking over a chair. "No more colonizing words," he said. He flung the wrecked ledger 
at her and reached behind the desk. The dog yelped and whined as he dragged it out. She lunged at him with a shriek, but he was quicker. She fought to grab the dog from him, but he was stronger. The dog squirmed in his arms and snapped at him. Even as she pummeled him with her fists the dog went limp in his hands. He tossed its body on the floor and returned to the kitchen table to pour himself another araq. She fell to her knees and took the dog in her arms. She felt him watching her. For a long time she rocked the little dog, petting it, finally curling down with it next to her. From where she lay Aziz's legs under the table looked like two stone pillars. She began to dream of escape through them.

When she opened her eyes again, the apartment was dark and quiet. The dog's body had gone stiff and cold. She crawled cautiously towards the kitchen. Gray dawn light poured over Aziz's head, which now rested on the table, and he snored softly. She got to her feet. The douk-douk, his slipjoint pocketknife, lay open near his head. She reached for the knife and her breath caught as she ran her finger along its blade, so sharp she hardly felt its cut. Aziz had brought this knife home with him from the war, still bandaged and still, mostly, Aziz. She had stared at its polished beauty. He, in turn, grabbed her hair and placed the knife where her ear met her face. During the war, he said, they had begun with Frenchmen's ears, he said, then their noses. He withdrew the knife and let go of her. She stared at him until he looked away.

Algerian nationalists had a saying about French Algerians' choice of departure: La valise ou le cercueil, in a suitcase or in a coffin. She chose a suitcase from the bedroom closet and threw some clothes into it, along with her papers and the lovely hat 
with seed pearls her mother had sent her from Paris, which she never wore, but kept as a memento. She slid the douk-douk carefully among the clothes and closed the suitcase . She wrapped the dog in a shawl and made for the door that led outside. Aziz was now on his knees in the main room, forehead pressed to the rug saying his prayers to Allah. When he saw her he got to his feet to tell her he was sorry about the dog, that he was going into hiding and would likely never see her again.

Her breath caught. He had not spoken so gently and clearly in her presence for a long time. "What are you saying?" she said.

"I have learned from Saïd and others that they are hunting me like a dog. I cannot stay here. You must find your way to France. You are not safe here.”

This was not the Aziz of the previous night, the one who had for months poured out abuse with each glass of araq. Her Aziz had returned to her. But now he was leaving. She went to him and touched his ruined shoulder. "Come with me," she said.

He bowed his head. "When these times have passed you can relive our memory in your heart."

They held each other all night and all the next day with the blinds drawn, waiting for night to fall. They rose only to eat and use the bathroom. She said she would find a way to send him money when she got to France, but he would not listen. At sunset he gathered a few things. "You took the douk-douk," he said.

She bowed her head. "I am afraid to move through the city at night alone."

"Keep it, then. A knife will not help me now anyway."

It was pointless to try to change his mind. "But what will I do without you?" she said. 
He stood in the doorway, silhouetted by the early dusk. "You will use your head and your heart. When it is all over will rejoice together no matter how far apart."

She tried to calm her mind as she collected her suitcase and wrapped her shawl around the dog's body, already fetid in the heat.

Gunfire, cries, and shouting continued in the distance. As the city burned, orange light filled the sky. She moved through scents of jasmine, cumin, shawarma roasting on spits, and the stench of rotten garbage. Sheer curtains, pregnant with breeze and melismatic strains from a radio or phonograph, billowed through a high window. Eddies of dust swirled bits of rag and paper. Here, too, the barricade had begun. Shops and cafés were boarded and silent. Spirals of barbed wire blocked alleys and stairways once populated by hookers, junkies, and alcoholics. She made her way down Ghaouli Abdelkader, past ponderous old colonial buildings that radiated the day's heat and exhaled stale air from cracks in their foundations.

The gates of the Christian cemetery were locked at night. She found the hole she knew in the wire fencing above the low wall and crawled through with the dog and her suitcase. She followed a familiar path with its riot of iris that overran the graves. Here sea breezes rushed in and tangled itself in cypress and palm fronds. The distant rattle of guns and explosions seemed dream-like in the cemetery. She came to a wide, flat gravestone carved with a simple cross above her father's name engraved on a brass plate. She brushed off a blanket of cypress needles to make a seat for herself. She told her father he would be proud of her. That she was writing poetry again. She thought about the timbered house perched on stilts in a cool river in France where she had lived as a child. But she did not know if she remembered the house or only images of it from all the 
stories her father had told her about it. She brushed more needles from the stone. "I am frightened, mon père. I do not know if I can return. But you are safe among friends here." She gathered her things and veered from the path to the edge of the cemetery where she dug a hole with her bare hands, lay the little dog inside wrapped in her shawl, and covered it with soil. Nearby, beneath a rock that marked the spot, she dug another hole until her fingers scraped against metal. She unearthed a cigar tin, brushed it off, and opened the lid. There were the little bundles of emergency francs she had been saving from the shops tobacco earnings.

She caught a late bus through the Sidi El Houari. The driver was an Arab with a thick gray mustache and a gentle smile. The bus was packed with wild-eyed pieds-noirs, French Algerians, some who huddled as if to make themselves look smaller while others engaged in combustible conversation about their plight.

The bus let most of them off at the Port of Wahran and she got off with them. The port was already choked with hundreds of panicked pieds-noirs with suitcases and blankets spread over the docks as they waited for passage on a boat to France. She moved among them now with her suitcase and tobacco tin, closer to the big ships whose sailors readied them while other men loaded and unloaded cargo. She asked one of the cargo men where she could buy a ticket. He pointed to a row of buildings. Catcalls and whistles followed her into the office.

The line to the ticket window extended out the door and quite a ways outside. When it was her turn at the window she requested immediate departure. The little French agent glanced over his glasses at her as he stamped papers with much fanfare. "Are you 
blind, Madame? Do you not see all the others awaiting accommodation?" He wore a hat that looked like a stiff blue cake. "You must wait your turn like everyone else."

"I see them." She opened the tobacco tin and slid a fat pile of francs toward him. "Let's pretend you do not." She followed the first pile with enough francs to pay for her passage.

His eyebrows lowered, then raised, then lowered again like horns locked in a fervent tussle. Finally he jiggled his necktie and gave it a decisive tug. In a discreet voice he said, "Of course we shall say nothing to anyone about this, Madame." He whistled slightly as he swept the notes beneath the counter. "Papers, please."

She handed him her papers. He scrutinized them with much self-importance before handing them back and produced a ticket, which he lay in her outstretched hand. "Çà va, Madame," he said, and shut the window. He turned the open sign around to CLOSED and drew down the shade. A wave of loud protestation swept over those still in line behind her. She had almost reached the door that led out to the docks when two brisk gendarmes closed in on either side of her and gripped her arms. "You will come with us please, Madame," one of them said as he relieved her of her tobacco tin. They firmly guided her back. His nose was red and his eyes red-rimmed, as if he suffered from allergies. The other one, who carried her suitcase, smelled of inferior hair pomade. They led her into the agent's office, sat her down in a polished wooden chair, and took positions on either side of her. Suddenly she felt very important.

The little agent discharged himself through a side door. He stretched his chin upward and squared his tie with vicious finality. His breathing was fast and audible, as if he had been running. "And so"- - he leaned close to her face, scowling — "the pretty little 
lady has been caught." He snatched her ticket and papers. "I will take these." To the guards he said, "Inspector Drouillard is waiting." He took her suitcase and the tobacco tin and led the way as they lifted her to her feet and dragged her into another room. There they pushed her down on a metal chair. The agent dropped her things on a table and handed her papers to the inspector who was drawing a diagram on a chalkboard. "She is yours, Inspector," the agent said. The guards again stood on either side of her while the inspector read her papers closely. After awhile he tossed them on the table.

The tobacconist was a businesswoman. She had dealt with plenty of corrupt men. "Excuse me, Monsieur," she said. "Tell me why you are detaining me. I have paid for my passage. I have done nothing wrong.”

"We shall see," he said.

"I demand to know on what authority do you hold me here against my will." She was emboldened by the knowledge that French authority was rapidly dissolving in Algeria.

"Those who correctly fight to preserve French Algeria, Madame," he said. "As a French Algerian. I have a right to legal counsel."

"You have broken the law. You have no rights, Madame." To the guards he said, "I have a phone call waiting. Search her things." He went off through another door.

The tobacconist crossed her legs and began to swing her foot. She felt both of the guards tense as she reached down to straighten one of her nylon stockings. "At least," she said, "may I have a glass of water?"

M. Pomade marched over to the spindly cooler. He pulled a paper cone from the dispenser, drew water from it, and drank it down. After refilling it he brought it to her. 
She tipped cup so the water poured onto the floor. M. Allergie's hand on her shoulder pressed down harder. "You know you are ignorant bullies," she said. M. Pomade raised his hand to strike her face, but checked himself. "A shame to bruise such a pretty face," he said, and moved over to the table. He opened the tobacco tin and grunted his approval as he stuffed a fistful of bills into his pocket. His hand moved to her suitcase, which he opened and riffled through her clothes, flinging them on the floor. The douk-douk made a sickening thud as it fell. In his effort to stoop for the knife, he stepped on her black hat with the net, the one from Paris, smashing it, and dropped the knife into his pocket. She made to lunge toward him but the M. Allergies pushed her cruelly against the chair as the inspector came back into the room. He motioned to the wet floor. "Did you have an accident, Madame?" He lit another cigarette and pulled up a chair, turning it around to sit so that its back separated them. His cigarette smoke curled into his hair as he scrutinized her. "We have knowledge that your husband is named Aziz Fournier and that he is an insurgent, working with the FLN. We believe you know his whereabouts."

She laughed.

"You have nothing to laugh about, Madame," he said as he waved the hot tip of his cigarette near her face.

Whisperings of voiceless people rushed through her mind. The night before Aziz had joined the National Liberation Front. Together in bed beneath moonlit striped sheets, telling her that people are everywhere the same. They float through life, coming and going like winds with no true place. Her French father beneath his stone. A fly with a broken wing crisscrossed the thin skin of grime on the window behind the inspector. At times it stopped and rubbed its hind legs together before it resumed its aimless course. 
Just as a fly had crawled over the crucifix above her father's bed just before something went out of his eyes and they flattened. Did the fly on the window connect the other side of the glass with freedom? And this? Inspector Drouillard was holding the douk-douk close to her face. "And this? Where did you get this?"

"The Monoprix," she said.

The inspector laughed. "I doubt that very much, Madame." He flicked the blade open. "You cannot buy one of these in a department store. They are what the Arabs use to cut trophies from French faces." He dropped his cigarette into the puddle of water at her feet where it hissed for a moment. Thunder rolled somewhere in the northwestern skies. She looked him in the eye with unmistakable contempt.

He closed the blade and slid it into his pocket. When his hand came out it held a small round tin. "Salt licorice?" he said opening the lid. "I am terribly addicted to it. I found these in a shop in Amsterdam last time I was there." Inside were black, diamondshaped pastilles. He popped one into his mouth, and its scent on his breath reminded her of Aziz. She continued to stare at him, defiant, motionless.

"Madame," he said, "the FLN is torturing people. Do you think we will not do the same if order is not restored?"

"Do you think people are so stupid? It is not the FLN that tortures." A loud clap of thunder coalesced with gunshots somewhere on the docks, followed by shrieks and shouts. Silhouettes flashed past the grimy window. The inspector started at the sound of breaking glass out in the ticket office. Inexplicably, indefensibly, he bolted from his chair towards the door, abandoning her to the guards who, now without orders, looked at each other and dashed after him. She hurried behind them through the empty ticket office 
where bright flames leaped and danced. The docks were a chaos of hysterical piedsnoirs shouting and colliding as they rushed from the docks with their belongings. Warm rain fell on her face. The wind smelled of brine, and the dark waters rolled to shore as stealthy and purposeful as death. "Over there!" someone shouted. She recognized the inspector's voice in the confusion. Her two guards raced toward her. Just as she sprang out over the open docks a deafening explosion sucked the air from her ears. The night twisted and convulsed around her as she dove into the black bay, its waters streaked with diesel and sulfur. Thunder rolled over the city. Clouds pulsed with light. Curtains of rain swept across her path. Beyond the breakwater she eased into long, steady strokes as she gathered her mind into a single purpose. Before her the slope of Djebel Murdjadjo lifted from the bay like a great, black shoulder. 
Fever

In those days the U.S. government provided boxes of food commodities to the poor, the unemployed, and the disabled. These boxes usually held the same food items: a brick of USDA butter, a jumbo box of USDA powdered milk, a loaf of Velveeta cheese, and a canister each of USDA honey and peanut butter. Each of the items was packaged in generic white with black letters with a warning that it was not for resale. I was disabled with a mysterious illness. Two hundred doctors had paraded past me where I sat on display in Letterman's General Hospital. Each shone a penlight into my mouth or my eyes or just smiled vaguely and cleared their throats in passing. My condition was certainly a debilitating one, they said. One of them wrote an article for the American Medical Association's journal about me, a slender twenty-two-year old woman with an atypical condition. Everything was temporary, even my ability to walk.

That summer my best friend Meg invited to stay with her and her family in their cabin in the redwoods near Ben Lomond in the Santa Cruz Mountains. I found a specialist in Cupertino who I visited weekly. He told me to take aspirin until my ears rang, prescribed new drugs, and sent me to labs for tests. He agreed with the consensus that I would be in a wheelchair before I reached middle age. Each month I received a check for $\$ 263$ and books of food stamps in the mail from the government. Each month I drove my Volkswagen to a warehouse to pick up my box of food commodities. Meg and I agreed to find a place to live down in Santa Cruz. After answering a few ads we rented a bedroom in a house with a view of the boardwalk and a guy whose face was diffused 
with the sadness of the world. His name was Kyle. His soft voice and hands fascinated me. He played Neil Young songs on an acoustical guitar. I brought out my tambourine and we improvised riffs together. I was sleeping with him after one week. By the second week I moved into his bedroom. I liked him for several reasons. First, because he made killer eggplant parmesan. A food magazine had interviewed him. He was famous in Boulder where he had grown up and his parents still lived. Second, I was intrigued that he had graduated from an expensive liberal arts college and drove an Austin Healey. Third, I had never met anyone who wore a blue star sapphire on both of his pinky fingers. But mainly I liked him for his soft voice and kindly eyes.

He cooked miraculous things using eggplant and my USDA commodities: salads, appetizers, sandwiches, casseroles, desserts and even drinks. When friends came over to eat his dinner he would not let anyone help him cook. He arranged the food with artistic care and personally delivered each plate with individual attention. He made everyone feel special. He served me last. At first I thought he had forgotten me. But after several of these gatherings I told myself that he was the king and I was his queen and we entertained guests in our castle, like some ancient ritual or a family tradition, a form of domestic intimacy. His rituals were flattering, but they said more about him than I was ready to hear.

Much of the time I was too sick to eat anything. I would come down with hallucinogenic fevers, sweats, and joint pains. The specialist in Cupertino could do nothing except send me for more tests and prescribe opiates. Unlike Kyle's eggplant, opiates eased the pain, broke the fevers, and lifted me into a state of euphoria. I would lie 
in bed all day aching and sweating and itching and flying and sleeping. I drew a lot of goddesses and wizards with a Kohinoor pen and black ink and filled them in with soft colored pencils. During these episodes I also read a lot of mystical books about people who took mind-altering substances including mescaline, psilocybin, peyote, lysergic acid diethylamide, and ayahuasca. Kyle ingested quite a lot of these substances himself that year. He would wander alone for hours in the redwoods above Santa Cruz. I saw less and less of him. Other times he took his guitar and stayed long into the night jamming with friends at the Catalyst, a coffee house under the old St. George Hotel on Pacific Avenue. When he got home he would bake peanut butter and eggplant cookies or grill eggplant Velveeta sandwiches.

One night he did not come home all. Or the next night. Or the next. Meg suggested he might have come down with gay fever. She did not like him as much as I did. When I was not sleeping I lay in his bed in sweaty, itchy euphoria half listening for the rumble of his Austin Healey. Weeks passed. Rent came due. Meg got tired of watching me change positions in bed. She moved her things out and went to live with her friends Leah and Garner up in Piedmont. The night she moved out I began to read The Teachings of Don Juan. I took it with me to read on the toilet. The house creaked and echoed in the wind. After a few pages the toilet vanished beneath me. So did the bathroom, the house, the city. I disappeared too. When I finished the last page gray morning light had tinted the bathroom. The weight of my body returned, cylinders of concrete encased in damp pajamas. I crawled down the long hall toward the bedroom because my legs would not wake up. 


\section{Evidence of Things Not Seen}

The term had ended at the medical teaching clinic. A few students staggered about, but for the most part the classrooms were dark and the hallways deserted. Two students, engaged to be married, took a table in the student lounge to wait for an appointment. They spread out their books and worksheets and packaged salads. He would study for a summer physics test and she would sit in the chair across from him and read introductory material on natural selection. The room smelled of onions, herbs, and butter. Along the wall inside the door a row of seven microwave ovens gleamed on a shelf. It held other groups of inanimate objects as well: eleven vacant tables with their chairs pushed in, four white refrigerators that hummed on one end near a sink and work counter, and two futons that faced each other in a corner at the other end. The couple sat at a table against one of the multi-paned windows with a view of some industrial buildings. While they ate their salads he read her a list of things, objects that may or may not have been in the room. Which item on the list, he said, was a hypothesis?
A. The moon is made of green cheese.
B. Atomic nuclei are the smallest particles in nature.
C. A magnet will pick up a copper penny.
D. Cosmic rays cannot penetrate the thickness of your physics book.

She read the list herself and pointed to B. He shot her a superior look and tapped the correct answer with his pencil. She stabbed a bit of lettuce. He showed her a second 
list. Which item was not a hypothesis.
A. Protons carry an electric charge.
B. Undetectable particles are some of nature's secrets.
C. Charged particles bend when in a magnetic field.
D. All of the above are scientific hypotheses.

She said she had no idea. He tapped B. His face emptied for a moment. He was looking at something over her shoulder. She turned to see what he saw. She had not noticed that a person had been stretched out in an upholstered chair in the nook beyond the microwave ovens. By the style of the clothes and the size of the orange and tan sneakers planted on an ottoman, the person was clearly male. An open gym bag rested on his lap. His upper torso and head were hidden.

Her fiancée had gone back to rustling through worksheets, but she could not help staring at the guy in the nook. There was no detectable rise and fall of breath beneath his T-shirt. She continued to stare to confirm her hypothesis. Her hypothesis seemed correct. She leaned close to her fiancée and posed a hypothetical question: Is he still alive? Her fiancée was holding down a page on vectors with his arms, his forehead corrugated in thought. He glanced up with a flash of irritation, dismissing her question as he bent over his page again. She turned her head to revisit her hypothesis. Seriously, she said. That guy’s not breathing. But her fiancée's face was too filled with other ingredients to let in her concerns.

She opened her book and tried to read. The words seemed to float off the page: "Variation exists within all populations of organisms. This occurs partly because random 
mutations cause changes in the genome of an individual organism, and these mutations can be passed to offspring." The pressure of lettuce she had eaten grew more insistent between two of her crowns. The dentist had told her the crowns were perfectly fine. She usually carried dental floss, but that day she had forgotten. She tongued the lettuce. It felt like a trace of river moss that had caught between two boulders. She dug a fingernail between the molars; her tongue kept returning to the trace of lettuce as she read. What she needed was some chewing gum. Across the hall, steps led down to a student store where they sold books, supplies, and snacks. She got her purse and made her way to the door with a brief glance toward the chair in the nook. Nothing had changed.

In the student store she had a choice between expensive peppermint gum and more expensive peppermint gum. The more expensive gum had xylitol in it. Its label claimed xylitol helped to prevent tooth decay. She settled on the more expensive gum because it would serve a dual purpose. The lounge doorway framed her fiancée making hand motions to himself as he wrestled with vectors. On her way back to their table her eyes darted back to the guy in the nook. She could not help herself. He still had not changed position in his chair. His chest still did not rise and fall with breath. She sat down and pushed out two pastilles of gum from hermetically sealed foil-backed plastic slots. She popped one pastille into her mouth and lay the other in the gutter of her fiancée's book. A vector, he told her, although she had not asked, was a quantity having direction as well as magnitude. He slid the pastille through his lips and chewed: One vector entering another.

The gum began to extract the lettuce. The pressure eased. She bent her head to 
focus on phenotypes. A student with a rust-colored beard rushed into the lounge, put a container in one of the microwaves and rushed back out. The microwave grumbled and the food inside it spit and popped. It gave off more of the onion-herb-butter aroma. The student returned for his hot food and disappeared out into the hall. Other students also came and went like ghosts. Outside the windows apple-colored leaves fluttered from trees. She thought of moonlight on a stack of cracked teacups, of the protracted sigh of all things as they diminished and fell. She went on reading. "Not all organisms with the same genotype look or act the same way because appearance and behavior are modified by environmental and developmental conditions."

When it was time to go to their appointment, they gathered their things to leave. She turned her head for one final glimpse toward the chair in the corner. A deep imprint in its upholstery was the only evidence anyone had ever filled it. 


\section{A Fly in Amber}

It was Sunday, Myra's day off from her summer job cashiering at Tuck's Hardware. She slid on Trudy's Circus Circus oven mitts and removed a sizzling iron pot from the oven. The pot held a whole roast chicken and the crisp smell of golden grease. She set the pot on the stove top and turned off the oven. The oven's heat made the air stuffy. She propped open the trailer door to let the air mix and circulate. Several houseflies droned in and disappeared. Aside from multiplying, disappearing was their greatest act. They were like birds, that way, that appeared and vanished across the sky in the space of a breath. The same way you never saw the bodies of wild animals that had died from natural causes, only those killed by traffic along the roadside.

Trudy, her lost lover, had removed the torn screen door and promised to replace it before summer, but it was already September. She had taken her gravikord and gone on tour with a band of troubadours in April. Myra had not heard from her since. She stared down into the moat of grease around the chicken and debated whether or not to make gravy. On the shelf among her cookbooks was the blue ring binder with recipes written in her grandma Estelle's spidery script. She took down the binder and thumbed through it for the lay gravy recipe made with milk and so thick that it lay wherever you put it. It had been a staple of her childhood, along with side pork, fried mush, and cosmic buttermilk biscuits. Her family called them "cosmic" because after eating them your day felt vast 
and right. On the other hand, gravy would add about ten thousand calories to the meal, which would only thicken further her middle-aged figure. She re-shelved the recipe book and poured herself the last of the coffee. Flies buzzed freely in and out of the bright doorway. An airplane droned overhead. MacCaskill's tractor-trailer fired up where it was parked out beneath the neon Paradise Trailer Park sign that floated high above the highway's edge. Travel trailers like Myra's were temporary, forever on their way to someplace else. They squatted on concrete slabs for brief interludes, too temporary to plant little gardens and stick in an American flag or a few pink plastic flamingos.

Coffee mug in hand, Myra slid along one of the trailer's padded seats that ran along either side of a drop-leg table. Sunlight splashed over the wall in bright patterns. Fat flies crawled over the window screens. Grandma Estelle who had identified as half gypsy, had set store by auguries and prognostications. She used to say that fat slow flies were a sure sign a storm was coming; that bushes draped with orb spiders' webs meant a wet winter ahead. Myra hadn't seen many webs yet that year, but the flies were certainly slow and fat. She blew on her coffee. The swarming flies would not settle. They made her twitch and scratch her arms. She was getting herself all worked up again thinking about things she had seen on television. She and Trudy had sat together once and watched a documentary on Trudy's travel TV they kept on the drop-leg table. The documentary was on starvation in Africa. It showed humans with skin stretched over their bones. Their haunted eyes stared at the camera lens as flies crawled over their faces and bodies, vertical corpses who did not flinch or fuss or brush the flies away. Myra had thrown herself against Trudy and let loose a torrent of wails. She bawled throughout the 
afternoon and into the evening. There was no end to the tears she had been saving up, a whole warehouse of them. Trudy had chastised Myra for these fits of drama over things she could do nothing about. Trudy was a practical person who saw the world in terms of math and music. She dug through her box of vinyl records and put a hurdy-gurdy song on the phonograph so that Myra she could hear its thrum and buzz collide like violins and bagpipes. But I don't sound like that, Myra had said. Do I? Her emotional fits were the second reason Trudy gave for moving out. The first was Myra's tendency to overeat. Trudy had left the box of vinyl records and the phonograph in the closet along with a few science books and a set of Allen wrenches. They were all Myra had to show for their three years of life together, besides the set of Circus Circus oven mitts Trudy had won in a crapshoot on their trip to Las Vegas.

Myra found a pencil stub and dug through the trash for an old envelope on which she wrote one of Grandma Estelle's favorites, a sing-song saying with its hint of responsibility and loneliness: "Down to Gahenna or up to the throne, she travels farthest who travels alone." She stuck the envelope on the refrigerator with a magnet.

MacCaskill's truck turned onto the highway with a series of loud, graveled roars and diesel fumes blew into the trailer along with another fly. Myra understood why the skeletal people no longer bothered to brush the flies away: Lifting a hand took strength, took energy. But she lived in America, land of coffee and doughnuts where you must have energy and furniture and flyswatters. A fly landed on her coffee spoon and two or three orbited the chicken. She got the blue plastic swatter that hung on its nail on the wall. The flies over the iron pot would not settle on the hot chicken, so she gave the fly 
on her spoon a whack and sent the spoon clanging to the floor. She looked for evidence of her victim, but saw none. It (or maybe a different one) landed on the edge of the table. Thwack! This time a solid hit. She collected the wreckage in a napkin and sprayed and sponged off the table. Another one landed on the cupboard above the chicken, daring her. It was a gamble. If she killed it and it fell into the pot, at least she would not be tempted to make lay gravy and would save herself about ten thousand calories. If, on the other hand, it missed the pot she knew she would wind up making the delicious gravy, eating it, and hating herself. Instead of moving the pot, she took aim and slapped the cupboard. It made a hollow wooden sound. The fly fell directly into the pot, suspended in the golden fat.

The fly, the golden fat. Once she had followed Trudy into a pawnshop that had a gravikord on display in its window. Trudy told the pawn dealer she wanted to see the gravikord, and she would eventually save up the money to buy it. But that day, while she waited for Trudy, Myra examined the trinkets in a glass display case. A fly in a clear yellow stone lay among the mess of beads and bracelets and keys. She pointed to it and asked Trudy what it was. Trudy said the stone was amber, fossilized resin from an ancient tree. The fly, she said, had gotten trapped in it millions of years ago, when the resin was still liquid. The way it curled there so perfectly frozen in a small yellow tear for all those millions of years made Myra sad in a way she could not explain.

The fly's legs wriggled now in the chicken grease. Its red headlight eyes stared at the sides of the pot through the fat, its back end hanging from its body like a tiny severed pickup truck. The wriggling legs began to slow until they stopped altogether. Inside the 
trailer the air had cooled and thickened; outside the open door the sky had yellowed. Thunder grumbled through the wide valley. In two months her job at Tuck's Hardware would be over. Come winter she would be moving on again. She told herself she was relieved, that strange sense of relief that comes from loss, that emptiness that drones in the ear, waiting. She lifted the chicken from the pot and nestled it in a covered dish to keep warm. The ghosts of African children surrounded her, waiting. 


\section{References}

Austen, Jane. Northanger Abbey. Oxford: Oxford University Press, 1945. Print

Castaneda, Carlos. The Teachings of Don Juan: a Yaqui Way of Knowledge. New York: Ballentine Books, 1972. Print.

Medusa. (n.d.). In Wikipedia, the free encyclopedia. Retrieved from https://en.wikipedia.org/wiki/Medusa

Praz, Mario. The Romantic Agony. Cleveland and New York: Meridian Books, 1963. Print.

Cat Stevens. "Miles from Nowhere." Tea for the Tillerman. A\&M, 1970 